\title{
Protection of Traditional Knowledge
}

Srividhya Ragavan

Texas A\&M University School of Law, ragavan.sri@law.tamu.edu

Follow this and additional works at: https://scholarship.law.tamu.edu/facscholar

Part of the Cultural Heritage Law Commons, Intellectual Property Law Commons, International Law Commons, and the Law and Society Commons

\section{Recommended Citation}

Srividhya Ragavan, Protection of Traditional Knowledge, 2 Minn. Intell. Prop. Rev. 1 (2001).

Available at: https://scholarship.law.tamu.edu/facscholar/373

This Article is brought to you for free and open access by Texas A\&M Law Scholarship. It has been accepted for inclusion in Faculty Scholarship by an authorized administrator of Texas A\&M Law Scholarship. For more information, please contact aretteen@law.tamu.edu. 

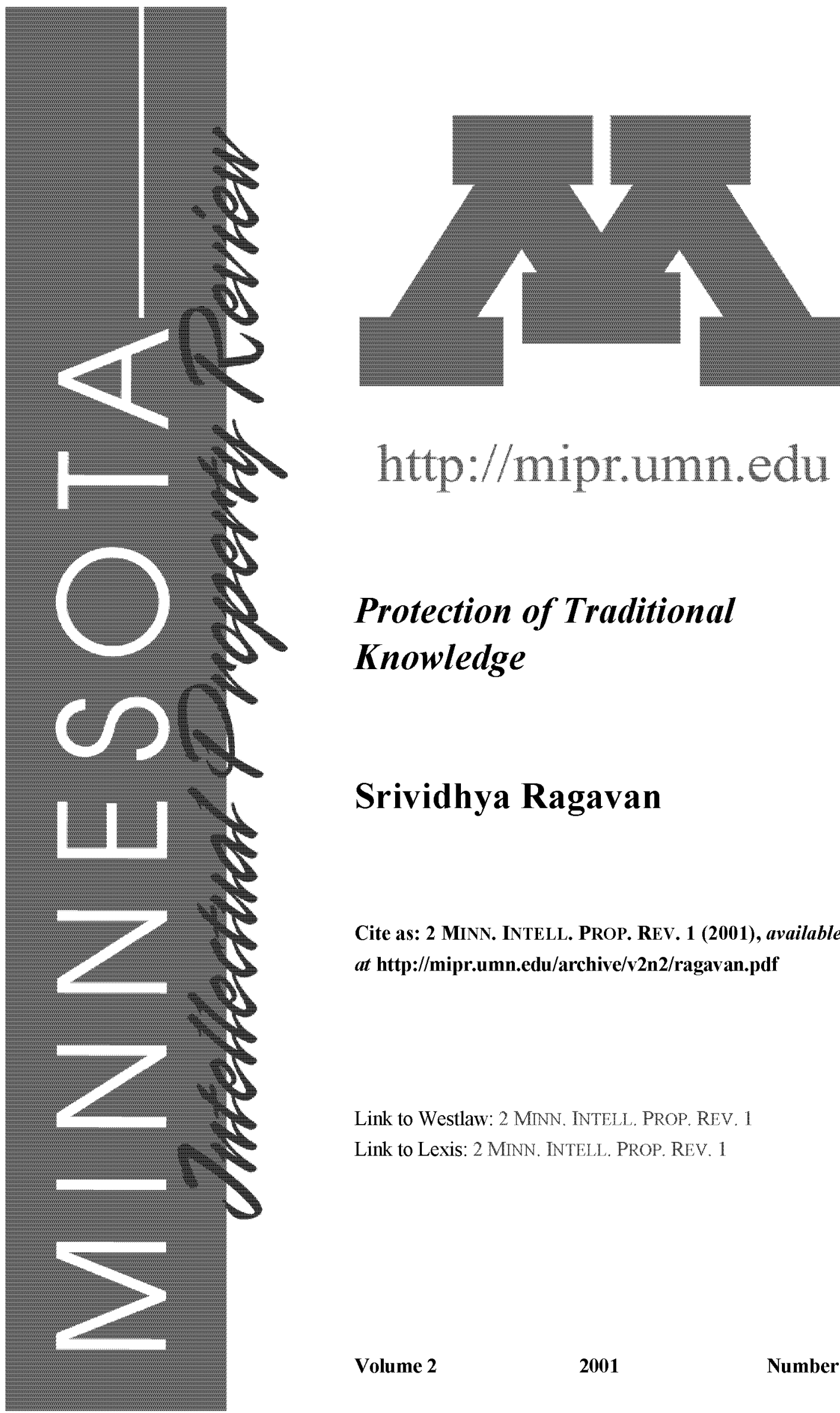

\section{Protection of Traditional Knowledge}

\section{Srividhya Ragavan}

Cite as: 2 Minn. Intell. Prop. ReV. 1 (2001), available at http://mipr.umn.edu/archive/v2n2/ragavan.pdf

Link to Westlaw: 2 MNNN. INTELL. PROP. REV. 1

Link to Lexis: 2 MNN. INTELL. PROP. REV. 1 


\title{
Protection of Traditional Knowledge
}

\author{
Srividhya Ragavan*
}

\section{INTRODUCTION}

Knowledge ${ }^{1}$ has been the most coveted possession of mankind since the industrial revolution. ${ }^{2}$ The industrial boom after the World Wars has highlighted the importance of the socalled intellectual knowledge. ${ }^{3}$ Recently, the importance of knowledge that has been in the public domain ${ }^{4}$ (and, therefore, accessible) has come into question. ${ }^{5}$ The pattern of evolution of

* At the time of writing this article, the author was heading the Center for Intellectual Property Rights Advocacy at the National Law School of India University, Bangalore, and was visiting the University of Washington as the first Texas Instruments Visiting Scholar. She is currently an SJD student at George Washington University. The author acknowledges the contribution made by Texas Instruments and thanks Texas Instruments for providing the funds.

1. Knowledge refers to the sum of what has been perceived, either through a theoretical data base or through practical experience, which leads to an in-depth understanding of the issue at hand. Knowledge has always been a coveted possession, beginning in the Old Stone Age when mankind evolved. However, the impact of technology and its importance was highlighted during and after World War II. This resulted in the realization that certain types of knowledge require protection for the benefit of the greater good, thus leading to rights over such knowledge. See also OXFORD ENGLISH DICTIONARY (2d ed. 1989).

2. The industrial revolution resulted in technology becoming a factor of growing importance in international trade and competition, particularly in the production of technology-intensive goods and services. Knowledge of new technology has become an important commodity, prompting a change in the format of intellectual property laws. See generally CARLOS M. CORREA, INTEllectual PROPERTY, THE WTO AND DEVEloPING CounTRIES: THE TRIPS AGREEMENT AND POLICY OPTIONS 3-4 (Third World Network 2000).

3. World War II caused countries to seek to build global economic relations, thus expanding global trade. The changing legal system prompted a recognition of the intellect as a property, making such intellectual knowledge (which is knowledge that was protect able on account of its importance) property. See generally Susan Riley Keyes, Process Patents: Protection and Weapon in the Global Marketplace, 22 SUFFOLK TRANSNAT'L L. REV. 715, 723728 (1999).

4. The knowledge that was not protected by the rights vested under law remained in the public domain.

5. The societies that hold the traditional knowledge have demanded the recognition of their knowledge as an intellectual property. The developing and least-developed countries feel that this knowledge is being plundered by the 
society, has been marked by a process by which the societies in developed countries have moved towards a more technological orientation. Consequentially, some traditional knowledge, including traditional practices, has been left behind and newer practices that are better, or at least considered better, are being used. Knowledge that is no longer part of the so-called developed societies, but retained by traditional societies has, of late, gained attention because of its value, materially and otherwise. There is, however, a difference between the knowledge vested in indigenous peoples and the corporate interests in using that knowledge. This leads to a gap between source materials and end producers, which can be described as the "gap between producers and users." Treatises assert that it is only the corporate interests that are finally rewarded. This increasingly threatens the viability of knowledge systems of indigenous peoples and local communities. ${ }^{7}$

This paper addresses the issues involved in attempting to protect, as intellectual property, the traditional knowledge prevailing within traditional societies. It outlines the debate on the issues and explores the possible ambit of property rights vested in the traditional knowledge. Finally, this paper, examines the slow but steady increase in the pace of the property holders to claim their rights. It is critical of the lack of appreciation, of the knowledge and the holders of such knowledge by the developed countries. In doing so, this paper highlights that in order for traditional knowledge to be protected effectively either within the prevailing intellectual property regime or by a separate regime, the bargaining power of developing countries must be strengthened. ${ }^{8}$ The paper argues that efforts to respect, protect, and understand

West. The developed countries have refused to recognize traditional knowledge as an intellectual property. See generally Craig D. Jacoby \& Charles Weiss, Recognizing Property Rights in Traditional Biocultural Contribution, 16 STAN. ENVTL. L.J. 74, 75-81 (1997).

6. Gurdial Singh Nijar, Legal and Practical Perspectives on Sui Generis Options (visited May 26, 2000) <http:/www.twnside.org.sg/title/generiscn.htm>.

7. See id.

8. The lack of bargaining power held by developing countries has led to the belief that the developed countries have used traditional knowledge to create patentable products based upon the prevailing knowledge in traditional societies. The same people who were instrumental in creating the knowledge are denied the benefits as the products become too expensive for them to afford. It is, therefore, argued that these communities should be entitled to some of the benefits that are derived from traditional knowledge. 
traditional knowledge will increase the need for intellectual property systems in developing countries, where such systems are currently weak. On the other hand, this article also suggests that that forcing the prevailing Western intellectual property rights upon developing countries without respecting the rights in traditional knowledge may have counterproductive results.

Part I details the lifestyle of the people targeted by this paper. Part II describes the various intellectual property systems and the difficulties involved in trying to fit traditional knowledge within one of the prevailing systems or any combination of the prevailing intellectual property systems. This part also explores the prospect of protection through a sui generis mechanism. The object is to focus on the theoretical as well as the practical difficulties in attempting to protect traditional knowledge. Part III details the various international agreements regarding intellectual property in order to highlight the international activities of indigenous people. The slow recognition of the intellectual property rights in the traditional knowledge is traced and evaluated critically. This part concludes that that none of the efforts have produced satisfactory results. Part IV examines the responses of courts in various jurisdictions to traditional knowledge issues in order to highlight the difficulty in recognizing and protecting such property rights. It argues that prevailing intellectual property regime is incapable of fitting the emerging issues within its mold. It also argues that there are inherent biases in protecting traditional knowledge. Part V highlights the efforts made by individual countries toward protecting traditional knowledge. 


\section{TRADITIONAL KNOWLEDGE AND INDIGENOUS SOCIETIES}

The term "traditional knowledge" refers to knowledge, possessed by indigenous people, in one or more societies and in one or more forms, including, but not limited to, art, dance and music, medicines and folk remedies, ${ }^{10}$ folk culture, biodiversity, ${ }^{11}$ knowledge and protection of plant varieties, handicrafts, designs, literature. ${ }^{1 \not}$

There are several definitions for the term "indigenous people," but essentially the term refers to people who characteristically exist under conditions of severe disadvantage relative to others within the states constructed around them. As a result of these disadvantages, they have been crippled economically and socially. Their cohesiveness as communities has been damaged or threatened, and the integrity of their cultures has been undermined. ${ }^{14}$ Typically, the following are characteristics of indigenous people.

a) They live in small societies and may not have access to formal education. They are unaware of the worth of the knowledge they possess. Such communities are found more often in developing and underdeveloped countries where there is a concentration of ethnocentric societies.

9. Article 8(j) of the Convention of Biological Diversity defines this term as "knowledge, innovations and practices of indigenous and local communities embodying traditional lifestyles relevant for the conservation and sustainable use of biological diversity." Convention on Biological Diversity, June 5, 1992, art. 8, 31 I.L.M. 818, 825-826. However, this article encompasses a wider ambit of traditional knowledge.

10. Medicines and folk remedies have a direct bearing on the product patent regime that TRIPS stands for. Most of the countries that will be subject to the product patent regime are economies that cannot and will not be able to afford the high prices for the drugs. Where the folk medicines or knowledge about these plants are taken to be used in pharmaceutical research, it is argued that the people who first possessed this knowledge should benefit in some form.

11. The use of traditional knowledge is associated with sustainable use and biodiversity. See David Downes, How Intellectual Property Could Be a Tool to Protect Traditional Knowledge, 25 COLUM. J. ENVTL. L. 253, 254-57 (2000) (arguing that the protection of this knowledge should be through the available intellectual property regime).

12. All these forms have practical uses and commercial marketability. Such forms of traditional knowledge have been used as a starting point for many industrial inventions. See id. at 254-55.

13. JAMES ANAYA, INDIGENOUS PEOPLES IN INTERNATIONAL LAW 3 (Oxford University Press 1996).

14. See id. 
b) Most often, the knowledge in question will be known to the entire community and remains exclusively within it. However, within the society, the knowledge is in the public domain.

c) Occasionally, knowledge of a special skill or art is limited to a few members of the community.

d) The knowledge and its components are normally required for a regular lifestyle within the society. It is passed down through generations while still retaining its original individuality.

e) Knowledge present in one form, such as art, music, or folklore, can be developed into other forms more understandable to the rest of the world. However, these informal innovations do not get formal recognition. ${ }^{16}$

f) Indigenous people often believe that intellectual property law is neither a necessary, nor a desirable, means of encouraging innovation within their communities. As a consequence, they are sometimes easily willing to share this knowledge, which leads to its exploitation. ${ }^{17}$ This situation gives raise to concern because, although the original holders have not acquired any benefit, the exploiters have benefited from the knowledge. ${ }^{18}$

\section{EFFECTIVENESS OF PRESERVATION UNDER THE PREVAILING SYSTEM}

This part examines the various intellectual property systems, within and also outside the existing framework of intellectual property laws. The possibility of structuring a regime for the protection of traditional knowledge is evaluated. Such a protection is discussed strictly within each area of intellectual property law. Protection by a combination of the various intellectual property laws is also examined. The object

15. See Downes, supra note 11, at 258-59. See also Anil Gupta, Building Upon What Poor are Rich in: Honey Bee Network Linking Grassroots Innovations, Enterprise, Investments and Institution (visited May 26, 2001) $<$ http://csf.Colorado.edu/sristi/papers/building.html>.

16. Gupta, supra note 15 .

17. See Naomi Roht-Arriaza, Of Seeds and Shamans: The Appropriation of the Scientific and Technical Knowledge of Indigenous and Local Communities, 17 MICH. J. INT’L L. 919, 926 (1996).

18. See id. 
of this part is to focus on the theoretical as well as the practical difficulties in attempting to protect traditional knowledge.

\section{A. Protection Inside the Existing Framework oF INTELLECTUAL PROPERTY LAWS}

The existing framework of intellectual property laws that are recognized internationally are those identified by the Trade-Related Intellectual Property Rights Agreement ${ }^{19}$ (TRIPS) and are governed by the World Trade Organization (WTO). ${ }^{20}$ They are: ${ }^{21}$
a) patents; ${ }^{22}$
b) copyrights; $;^{23}$
c) trademarks; ${ }^{24}$
d) geographical indications; ${ }^{25}$
e) protection of undisclosed information $;^{26}$
f) layout designs of integrated circuits; ${ }^{27}$ and
g) industrial designs. ${ }^{28}$

19. See Agreement on Trade - Related Aspects of Intellectual Property Rights, Apr. 15, 1994, 33 I.L.M. 1197 [hereinafter TRIPS Agreement].

20. See Marrakesh Agreement Establishing the World Trade Organization, Apr. 15, 1994, 33 I.L.M. 1144 [hereinafter WTO Agreement].

21. See TRIPS Agreement, supra note 19, part I, art. 1, at 1198 ("for the purposes of this Agreement, the term 'intellectual property' refers to all categories of intellectual property that are the subject of Sections 1 through 7 of Part II").

22. See id. part II, $\& 5$, art. 27, at 1208 (stating "patents shall be available for any inventions, whether product or process, in all fields of technology provided that they are new, involve an inventive step and are capable of industrial application").

23. See id. part II, $\S 1$, art. 9, at 1201 (providing for the protection of expressions as copyrights).

24. See id. part II, art. 15, 1203 (providing for the protection as trademarks of "any sign, or any combination of signs, ... inherently capable of distinguishing the relevant goods or services").

25. See id. part II, $\S 3$, art. 22 , at 1205 (geographical indications are "indications which identify a good as originating in the territory of a Member... where a given quality, reputation or other characteristic ... is essentially attributable to its geographical origin").

26. See id. part II, $\$ 7$, art. 39, at 1212-13 (providing for the protection of confidential information in order to avoid unfair competition).

27. Article 35 of the TRIPS Agreement protects the topographies of integrated circuits. See id. part II, $\S 6$, art. 35 , at 1211 . These are meant specifically for circuits made from semiconductor chips. See id. part II, $\S 6$, art. 36 , at 1211 .

28. See id. part II, $\S 4$, art. 25 , at 1207 (providing for the protection of independently created industrial designs that are new or original). 
Several arguments on the pros and cons ${ }^{29}$ of protecting traditional knowledge within the prevailing regime of intellectual property laws have been raised. These arguments have essentially been either moralistic or emotive in nature. The moralistic arguments focus on the western impression that every person has a moral right to control the product of his or her labor or creativity. ${ }^{30}$ The developing countries have argued that their traditional knowledge has been the basis for the research leading to high-priced inventions, the benefit of which is reaped by developed nations. ${ }^{31}$ Interestingly, the core of the western moralistic theory focuses on providing limited incentives to private inventors in exchange for creativity that benefits the greater public good. ${ }^{32}$ In any case, the intellectual property laws have developed into a technical, rather than a moralistic, area of law. The emotive arguments have focused

29. The perception of intellectual property is different in the West, which has a more capitalist orientation than developing countries, and believes in the preservation of intellectual property with the idea that it will benefit the public later. The societies that hold this knowledge strongly believe in sharing knowledge and consider it a part of the public domain. See generally RohtArriaza, supra note 17, at 926. See also Ruth L. Gana, Prospects for Developing Countries Under the TRIPS Agreement, 29 VAND. J. TRANSNAT'L L. 735, 757 (1996) (Ms. Gana states that the developing countries have remained in the periphery and that the relationship between the developing countries and the West has been one of deep mistrust with the developed world). However, both of these articles point out that the developing and leastdeveloped nations were not ready to shoulder the responsibilities of the Western world while crying for benefits from the Western world in return for colonialism. But see CORREA, supra note 2 (discussing the factors that lead to the mistrust between the developing countries and the West).

30. Professor Downes states that based upon the moralistic argument intellectual property rights are a balance between private benefit and public good, and that in the case of traditional knowledge the clear calculation to determine whether there has been inequality is not easy. See Downes, supra note 15, at 261-64. See also Lakshmi Sarma, Bio Piracy: Twentieth Century Imperialism in the Form of International Agreements, 13 TEMP. INT'L \& COMP. L.J. 107 (1999).

31. A strong case has been made that compensation should be received for traditional bio-cultural knowledge due to the value created and time saved in identifying plants used in medicine or by cultivating specific crop varieties obtained through the labor and time invested in selecting, nurturing, conserving, and improving traditional varieties over a long period of time. Professor Jacoby argues that traditional bio-cultural knowledge not only guides researchers, but also provides them with unique sources and materials. $\mathrm{He}$ also points out that several companies in the United States currently take ethno-botanical data as part of their research. See Jacoby, supra note 5, at 85.

32. See Downes, supra note 15, at 261-62 (citing JAMES BOYLE, SHAMANS, SOFTWARE, AND SPLEENS: LAW AND THE CONSTRUCTION OF THE INFORMATION SOCIETY 124 (1996)). 
on the economic realities of the developing countries, with both developed and developing nations accusing the other of pirating information. ${ }^{33}$

\section{Patents}

A patent is a statutory monopoly granted for a limited period of time by the state for inventions having commercial application. $^{34}$ It encourages research and development by offering a reward for developing an invention and making it public after a specified period of time. ${ }^{35}$ Issues of patentability arise with respect to folk medicines. Folk medicines are not limited to the medicinal practices of indigenous people. They include knowledge of traditional cures, the curing properties of herbs, leaves, and other treatments not known hitherto the rest of the world. It also includes the genetic makeup of people who are immune from diseases thus far considered incurable. ${ }^{36}$ Multinational corporations, aware that folk medicines can be developed as medicines with worldwide market power, ${ }^{37}$ have sought to patent or acquire rights over forms of these treatments. For example, the rosy periwinkle, unique to the Madagascar region, contains properties that can cure certain forms of cancer. ${ }^{38}$ The anti-cancer drugs vincristine and vinblastine, developed from this plant, resulted in annual sales of around USD 100 million for Eli Lilly. ${ }^{39}$ The island and its people received virtually nothing.

While examining members of the Pandilla people of North

33. The developing countries felt their traditional knowledge has been pirated by the developed nations while the developed nations accused the developing countries of pirating their intellectual property. See id. at 261-64.

34. R. Muralidharan, Everything on Patents, WIPRO INFOTECH HANDBOOK ON INDUSTRIAL PROPERTY LAW, 1997. See also David R. Boyko, Antitrust Limits on Exploiting Intellectual Property Rights, 13 ST. JOHN's J. LEGAL COMMENT. 171, 172 (1998).

35. See Julia Hodge, $\S 112$, II 6 Claim Interpretation and the Doctrine of Equivalents: An Invitation to Confused Thinking, 17 SANTA CLARA COMPUTER \& HIGH TECH. L.J. 203, 204 (2000) (citations omitted).

36. See Roht-Arriaza, supra note 17, at 921-27.

37. See id. See also Downes, supra note 15, at 254-55.

38. See Roht-Arriaza, supra note 17, at 922 (citing Elizabeth Pennisi, Hair Harvest: Bacteria Turn Roots into Chemical Factories, 141 SCIENCE NEWS 366 (1992)).

39. See id. (citing Shayana Kadidal, Plants, Poverty, and Pharmaceutical Patents, 103 YALE L.J. 223, 224 (1993)).

40. See id. (citation omitted). 
and South America, the research team lead by Darrel Posey and Graham Dutfield ${ }^{41}$ on Rural Advancement Foundation International (RAFI) of $\mathrm{Canada}^{42}$ reported that doctors had discovered a local woman who had immunity to leukemia. The immunity gene was immediately isolated and a patent was sought.

The Ayahuasca ${ }^{44}$ is a traditional medicine central to the lives of the people in the basin of the Amazon for decades. ${ }^{45}$ Loren Miller of the International Plant Medicine Corporation recently applied for a U.S. patent to be recognized as the "inventor," and the patent was granted. ${ }^{47}$

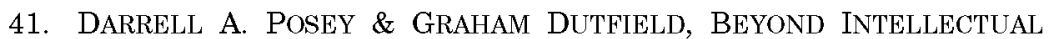
PROPERTY, (International Development Research Center, Canada) (1996).

42. RAFI is an international non-governmental organization headquartered in Winnipeg, Manitoba, Canada. It is dedicated to the conservation and sustainable improvement of agricultural biodiversity, and to the socially responsible development of technologies useful to rural societies. RAFI is concerned about the loss of genetic diversity-especially in agriculture-and about the impact of intellectual property on agriculture and world food security. See Rural Advancement Foundation International (visited Aug. 22, 2001) <http:// www.rafi.org/web/about.shtml>.

43. See Posey and Dutfield, supra note 41 , at $26-27$.

44. See Ayahuasca FAQ (visited Aug. 20, 2001) <http:/ayahuasca.com/cgibin/faq.pl>. The Ayahuasca is a brew which is also called the yage or Yaje in Columbia and is known in Equador, Peru and Brazil. See $i d$. It is prepared from a plant called the vine banisteriopsis caapi. See id. Sections of vine are boiled with leaves from any of a large number of potential admixture plants resulting in a brew that contains the powerful hallucinogenic alkaloids harmaline, harmine, d-tetrahydroharmine, and often N,Ndimethyltryptamine. See id. This medicine has been used for decades in order to enter the sacred supernatural world, to heal, divine, and worship. See id.

45. Richard Spruce, a British teacher, notes in his book, Notes of a Botanist on the Amazon and Andes, that in 1851, while exploring the upper Rio Negro of the Brazilian Amazon, he observed the use of yage. See RICHARD SPRUCE, Notes of A BoTANIST ON THE AMAZON AND ANDES (Alfred Russel Wallace ed. 1908). Spruce encountered it twice in Peru in 1853, which appeared in his book in 1908. See id. Spruce notes that he "suspected that additives were responsible for the psychoactivity of this beverage," and sent samples to England for chemical analysis which were "still psychoactive when examined in 1966." Id.

The first widely read description of yage practices was published in 1858 by Manuel Villavicencio, an Ecuadorian geographer. The experience made him feel he was flying to most marvelous places. Describing how natives responded, he reported that natives using this drink were able to foresee and answer accurately in difficult cases, be it to reply opportunely to ambassadors from other tribes in a question of war; to decipher plans of the enemy through the medium of this magic drink and take proper steps for attack and defense. Id.

46. See ESTELle DORIS LONG AND ANTONY D'AMANTO, INTERNATIONAL INTELLECTUAL PROPERTY 1056 (WEST GROUP 2000). There have been several 
Several incidents have occurred which developing countries describe as unauthorized appropriation of their knowledge. ${ }^{48}$ These countries find this appalling, especially since most of such indigenous people are living in conditions devoid of human rights, which the UN Charter regards as a condition for living with human dignity. These incidents are often viewed in the developing counties as instances where third parties steal information to expand their own industries and increase profit margins. That the developed nations are aware that if the holders were given even a portion of the profits, it would greatly improve their living conditions, only enhances the feelings of bitterness. This has led the indigenous people to organize themselves to protect their knowledge and resources by various means.

The initial strategy adopted to combat such exploitation was protest. For instance, in the case of the Pandilla people mentioned above, the patent application evoked protests from international communities, RAFI protested at the GATT Secretariat and at the Intergovernmental Committee on the Convention on Biological Diversity. ${ }^{49}$ The patent application was withdrawn, ${ }^{50}$ though the cell line has not been returned. ${ }^{51}$

protests against his application organized by the Coordinating Group of Indigenous Organizations in the Amazon Basin (COICA). See Bob van Dillen and Maura Leen, Biopatenting and the Threat of Food Security-A Christian and Development Perspective (visited 2000) <http://www.cidse.org/tglppcon.

$\mathrm{htm}>$.

47. U.S. Patent No. 5752/1986.

48. Many LDCs view the use of their biocultural contributions to biotechnology companies in developed countries to create commercial products as an example of the traditional colonial paradigm of exchanging their natural resources for manufactured goods. See supra note 5 (detailing the general sentiments of these people). See Craig Jacoby and Charles Weiss, Recognizing Property Rights in Traditional Biocultural Contributions, 16 STAN. ENVTL. L.J. 74 (1997) (discussing the various bio-cultural knowledge that has been misused by the West).

49. See U.N. Doc Biodiv. No. 92-7807 (visited Aug. 22, 2001) $<\mathrm{http}: / /$ www.biodiv.org $>$.

50. Cost was cited as the reason for withdrawal.

51. RAFI also has formed other protests. See Rural Advancement Foundation International (visited Aug. 22, 2001) <http://www.rafi.org >. For example, in the case of the "Terminate Terminator Technology" (seed sterilization), RAFI is sending personal letters to more than 550 ministers and senior officials responsible for agriculture, environment, and patent offices in 140 countries. See id. The letters ask cabinet officers to assert national sovereignty over their seed supply and to ban the seed sterilization technology outright. See $i d$. The letters also ask ministers to reject each individual Terminator-type patent pending within their jurisdiction. See id. Ministers are receiving a status report on key Terminator patents in their countries. See 
The indigenous tribe ${ }^{52}$ is still concerned since the cell line is being preserved under the Budapest Treaty, which allows for preservation for up to thirty years. ${ }^{53}$ A few years there is a danger of this cell line becoming a generic property without any patents. In effect, that will leave the holders without any benefit whatsoever.

In some cases, the respective governments have also intervened to challenge or oppose the patent applications. For example, in 1995 the US Patent Office granted a patent for turmeric, a substance used for cooking and healing in India. ${ }^{54}$ The Indian Council for Scientific and Industrial Research (CSIR) opposed the application, claiming "prior art.,55 The CSIR presented documents from "ancient Sanskrit text and a paper published in 1953 in the Journal of the Indian Medical Association, ${ }^{56}$ proving that the healing properties of turmeric had been in use for thousands of years in India. The patent was ultimately rejected because of the challenges. ${ }^{57}$

The patenting of neem was yet another long drawn fight for India. Neem has been used in Indian villages for centuries. ${ }^{58}$ In both rural and urban India, neem leaves are used even today

id. Pat Mooney, RAFI's Executive Director says, "Many governments are unaware that the World Trade Organization allows countries to reject individual patents on the grounds that they are contrary to ordre public (public morality and/or a threat to health or the environment).... The WTO also allows governments to ban the entire technology. Both steps should be taken." Id.

52. The tribals are indigenous people who have organized themselves within tribes. Each tribe has its own customs and practices giving it a distinct identity from any other tribes around.

53. A total of 26 institutions are recognized by the Budapest Treaty for the deposit of microorganisms as a part of the patent procedure with the WIPO, now validated by the WTO and the TRIPS. See id. One of these is the ATCC (American Type Culture Collection), a private organization based in the United States. See id.

54. See LONG AND D'AMANTO, supra note 46, at 1056 . Over six applications were filed on March 28, 1995 and rejected on August 13, 1997 after a re-examination. See id.

55. See Trade and Development Case Studies (visited Aug. 22, 2001) $<\mathrm{http}: / /$ www.itd.org/issues/india6.htm $>$.

56. $I d$.

57. See LONG AND D'AMANTO, supra note 46, at 1057.

58. 'In India, the neem tree is known as the 'curer of all ailments.' For centuries, Indians have used neem tree bark to clean their teeth; neem-leaf juice to prevent psoriasis and other skin disorders and to control parasitic infections; and neem tree seeds as a spermicide and an insecticide." Id. at 1075. Neem extracts have been used by Indians to control both malaria and trypanosomiasis infections and to reduce fever, pain, and inflammation associated with these parasitic diseases. See id. 
as a cure for chicken pox. ${ }^{59}$ The US Patent Office granted a patent on a neem extract, Azadirachtin, which has storage properties, to W.R. Grace Inc. ${ }^{60}$ The Indian government filed a complaint with the US Patent Office, though the patent has not yet been revoked. ${ }^{61}$ W.R. Grace, along with the US Department of Agriculture, also filed for a patent for neem for as anti-fungal product with the EU Patent Office. ${ }^{62}$ This patent was eventually revoked after six years when, at a hearing in Munich, the manager of an Indian Agricultural company proved that he had been using the neem extract for the same purpose several years before the patent was filed. ${ }^{63}$ The corporate vice president of W.R. Grace earned India's resentment when he dismissed the Indians' knowledge of the plant's uses as "folk medicine." Interestingly, it was testified that European countries were aware of the medicinal use of neem in India for a long time. ${ }^{65}$ However, because the issues

59. See id.

60. See Jacoby and Weiss, supra note 48 , at 75 .

The Grace patent covers both a method of stabilizing azadirachtin in solution and the stabilized azadirachtin solution itself. While naturally-occurring neem extract has a shelf-life of only a few weeks, storage-stable azadirachtin retains its potency for several years, thereby making it both more valuable to the pesticide industry and more useful to farmers. In March 1994, the EPA registered Neemix ${ }^{\mathrm{TM}}$, Grace's stabilized azadirachtin solution, for use on food crops. Neemix ${ }^{\mathrm{TM}}$ is the first product derived from the neem tree approved for such use in the United States.

Id.

61. Id

62. See BBC News (visited May 26, 2001)< http://news.bbc.co.uk/hi/ english/sci/tech/default.htm>.

63. See Pan Asia Networking < http://www.panasia.org.sg/twm.htm>.

64. While the Grace story is one of successful Western improvement and commercialization of traditional biocultural knowledge, it is a horror story of inequity in the eyes of some traditional peoples. In response to the issuance of the Grace patent, a coalition of 200 organizations from 35 different nations filed a petition with the U.S. Patent Office seeking to invalidate the patent. One of the petitioners decried the Grace patent as an act of "intellectual and biological piracy.

Jacoby \& Weiss, supra note 60 , at 76 .

65. See id. The author describes the popularity of neem and the knowledge of its use in India among some Europeans, stating,

our past warnings on piracy of patent rights for neem have gone unheeded by the Indian government . . . it is only recently, when foreign companies started to patent the plants, that the authorities in India have woken up only to find that it is a bit too 
with respect to prior art has not been resolved yet at an international level, neem will not fall within the definition of prior art. Unfortunately, most traditional medicines in their natural form often do not qualify for patent protection. In the United States, to qualify as an invention, an item has to be useful, novel, and non-obvious. ${ }^{66}$ Most jurisdictions apply this threefold test. More importantly, TRIPS has adopted a similar test. $^{67}$ Although traditional medicines have many uses, they often fail to meet the novelty and non-obvious requirements of patent applications.

Anything already in the public domain is not considered novel as it is "prior art." 68 Since traditional knowledge generally has been public within the society for centuries, it falls within the public domain. ${ }^{69}$ The US Patent Act specifies that the invention should not be obvious to one skilled in the art. $^{70}$ Traditional knowledge will not qualify for this test either-making patent protection of this knowledge difficult.

In any case, the US and most other jurisdictions operate on the "first to file" system, i.e., the person who files first gets the patent. ${ }^{71}$ These jurisdictions restrict their search for use in the public domain to the country in which the patent application is made. This is in spite of the fact that the subject of the patent may have long been in use in public domain in other parts of the world. The US has been criticized for granting patents when the applications' contents are considered public domain in other countries. ${ }^{72}$ While discussing the turmeric case, Dr. Vandana Shiva, a noted activist, ${ }^{73}$ criticized the fact that under

\footnotetext{
late in the day to redress the situation, a German 'nature healer', who administers herbal remedies for curing ailments of his

$I d$. patients, on condition of anonymity.

66. See 35 U.S.C. $\$ \S 101,102$ and 103 (2000).

67. Article 27(1) of TRIPS details that patents shall be granted provided they are new, involve an inventive step, and are capable of industrial application. See TRIPS Agreement, art. 27(1), 33 I.L.M. The footnote to the term "inventive step" clarifies that the term "inventive step" and "capable of industrial application" may be deemed to be synonymous with the terms "nonobvious" and "useful" respectively. See $i d$.

68. See 35 U.S.C. $\$ 102(2000)$.

69. Article 54 of the European Patent Treaty also refuses to grant patents to things that fall within the purview of "the state of art."

70. See 35 U.S.C. $\$ 103(2000)$.

71. Martin J. Adelman et al., Cases and Materials on Patent LaW 1 (1998).

72. See generally Jacoby \& Weiss, supra note 48 .

73. See Biomedics: Misguided and Risky Panacea (visited Aug. 22, 2001)
} 
the US law the prior art search does not cover practices that exists in other parts of the world, stating:

Section 102 of the U.S. Patent Act does not provide for a rule-bound method to be used by patent examiners for determining which materials will defeat a patent application. Prior foreign activity anticipates a US patent only when the foreign activity is in a tangible, accessible form such as a published document or a patent. However, prior foreign knowledge, use and invention are all excluded when the question of prior art is considered in relation to a US patent application.

Dr. Shiva urges the WTO to examine the patent requirements in the United States as applied to foreign substances. ${ }^{75}$ Furthermore, patents for inventions that include knowledge of traditional medicine as a component are difficult to obtain. For instance, in the US a biotechnological invention can be patented. Where such an invention is developed using some traditional knowledge, the applicant never acknowledge the contribution from the traditional sources and the nexus between the end product and the initial knowledge. This is not a bar to patentability.

\section{Copyright}

Copyright vests the right of authorship in the creator of a work and enables him to prevent the misuse of his work. ${ }^{77}$ The issue of copyright arises in relation to "folk materials," which consist of traditional knowledge in art form. "Folk materials"

<http://www.twnside.org.sg $>$.

74. Id.

75. See id. Dr. Shiva also states that other patent applications, including those for "Amla, Jar Amla, Anar, Salai, Dudhi, Gulmendhi, Bagbherenda, Karela, Rangoon-ki-bel, Erand, Vilayetishisham, Chamkura" have to be reexamined. See id. She insists that these applications are in themselves a reflection of the extent of bio piracy. See id. See also supra note 58.

76. See Downes, supra note 15, at 264. Professor Downes argues that patent applications should contain details of the genetic resources and the informal knowledge. See $i d$. at 256 . He concludes that this will not be a major change from the prevailing system. See id. But see, Jacoby and Weiss, supra note 48 (arguing that patent protection cannot be given for traditional knowledge unless the entire system is changed).

77. See generally, Berne Convention for the Protection of Literary and Artistic Works, Paris Text, 1971.

78. WEBSTER'S DICTIONARY includes "people of a tribe," "as carriers of culture representing composite customs of society" as the definition of folk. 
include folklore, folk music, ${ }^{79}$ drama, and other folk-related artistic endeavors, all of which appeal to a wide market today. The rustic and ethnic qualities of folk arts depict a sense of originality which modern consumers find very appealing. It reflects natural senses that would otherwise be impossible to fathom for people who have been cultured with layers of dictated behavior required for the "civilized society."

Of all the folk material, folklore has been most frequently infringed upon, followed by folk art. There have been several cases of misuse, exploitation, mutilation, or dilution of these materials, threatening the concept of "originality of expression." Exploitation ranges from copying songs or mixing songs with other forms of popular music, to displaying and collecting sacred items. Typically, remixed songs attain commercial popularity. Folk art is also an object of infringement. Aboriginal art, ${ }^{80}$ particularly paintings, is a major attraction in Australia and is, therefore, a major source of infringement. The artistic customs of the Australian aboriginal people ${ }^{81}$ are also exploited and infringed in Australia. One documented incident of misuse involved the book, Mutant Message Down Under. ${ }^{82}$ The book contained an account of Morgan's alleged travels among "cannibalistic" western Australian aboriginal tribes. The book remained on the United States' best sellers' list for twenty five weeks and was short-listed for the 1995 American booksellers book of the year. The author merchandised CDs and videos to promote the book and her form of new age spiritualism. Following a detailed investigation, the Kimberley Law Center revealed that the author had never visited Australia, and subsequently she confessed that the work was a hoax. ${ }^{83}$ The inadequacy of

79. The phrase "folklore" means the words of folk songs and the phrase "folk music" means the music with or without the words.

80. There are several forms of Aboriginal art. See Aboriginal Art \& Culture Centre (visited Aug. 22, 2001) <http://www.aboriginalart.com.au> The Aborigines are not a single homogenous society. Each group differed in its culture and social framework. See id. On account of this the art, music and other expressions also differ vastly and reflect the group to which the creator belongs. See id.

81. The indigenous people of Australia are one of the world's oldest living cultures. See Australasian Legal Information Institute (visited Aug. 22, 2001) $<$ http://www.austlii.edu.au/IndigLRes.html>. Aborigine refers to a person of aboriginal descent identified and recognized as such. See id.

82. MARLO MORGAN, MUTANT MESSAGE DOWN UNDER (1994).

83. WIPO ROUNDTABLE ON INTELLECTUAL PROPERTY AND TRADITIONAL KNOWLEDGE, MiCHAEL BLAKENEY, WHAT Is TRADITIONAL KNOWLEDGE? WHY 
copyright law is highlighted by the fact that even this work, an example of blatant misuse, can still be protected by copyrights, simply because originality of expression of the author's idea, in spite of the fact that it violates the integrity of indigenous people. On the other hand, it can be validly argued that intellectual property protection is not related to the issue of integrity of the subject matter in issue. The indigenous people argue that other than to make a hue and cry, there is no other way to tackle such violations within the prevailing legal mechanisms. They submit that such violations depict the indigenous people in a completely inaccurate and sometimes degrading manner. It is also a violation of the sacredness of their art and community, since the number of people ${ }^{84}$ trained in folk art may be limited, again reflecting its sacred nature. ${ }^{85}$ Whether protection of traditional knowledge should take the sacredness of the art and other factors into consideration is another issue to be decided. On the one hand, this may be very desirable theoretically however, this has the danger of making the issue very subjective.

Other similar forms of misuse include instances of the indigenous people being made a commodity for commercial profit. In one case, a tribal person noticed that images of his family were printed on a T-shirt sold in front of the Earth Summit. He objected and was appalled by the fact that the images were being made some kind of advertisement to the rest of the world. ${ }^{86}$ In this case, there is very little that copyright law can do to protect against such violations. In fact most of these cases are resolved not under the prevailing intellectual property regime, but by the indigenous people and the local non-governmental organizations.

Copyright is also inadequate to protect arts of the indigenous people. ${ }^{88}$ For example, in a dance, the performer

SHOULD IT BE PROTECTED? WHO SHOULD PROTECT IT? FOR WHOM?: Understanding The Value ChaIn, CENTER For LaW STUdies, QueEn MaRY AND WEST FIELD COLLEGE.

84. Examples that are similar to these are also found in India such as the Kathakali from Kerala and Yakshagana from Karnataka.

85. See Ozemail (visited May 26, 2001) $<$ http://www.ozemail.com.au/sacredsites.htm> (detailing explanations of the sacred beliefs of the aboriginal culture).

86. See Postings of Dieter Dambiec,d.dambiec@student.caberra.edu.au, $<$ http://www.t0.or.at/scl.html>.

87. See ANAYA, supra note 13.

88. See Michael Blankley, Milpurrurru \& Ors v. Indofarm \&Ors: Protecting Expressions of Aboriginal Folklore Under Copyright Law, E LAW, 
has a style manifested in several ways but as a sequential unique style over several performances. ${ }^{89}$ Where the dance is removed from the main theme and song, and incorporated, for example, into western music, there is no protection if the dance was copied without permission, as the dance will be deemed to be in the public domain. Similarly, where a tribal painting is copied with minor modifications, the indigenous tribes will have no rights under copyright law. ${ }^{90}$ The copy can depicts a subject in a different manner, thereby conveying a meaning different from what was intended. In the long run, such activity will dilute the tribal customs.

So far, the courts have tended to deviate from established principles to decide such cases. Alternatively, they choose to carve out an exception to afford protection especially where the modus does not fall strictly within the definition of copyright violation but there is a clear violation of the rights of the indigenous people. Some cases are settled outside courts; for example, in 1989, Mr. John Bulun, an aboriginal artist, discovered some of his paintings were reproduced on $\mathrm{T}$ shirts without permission. ${ }^{91}$ He sued for copyright violation. ${ }^{92}$ The court was considering the possibility of breach of confidence when the company withdrew the T-shirts from sale and decided to settle the dispute. This resulted in other artists suing the same company, which proved the extent of violation. There is also a strong possibility that the artists did not go to court earlier as they were not aware of their rights over the art. The decision of Yumbulul $v$ Reserve Bank of Australia, ${ }^{93}$ is yet another case demonstrating the inadequacy of copyright law. The court considered customary rights. However, the decision was eventually based on a very technical interpretation of the prevailing western intellectual property law. The decision exhibited a lack of appreciation of subtle, but apparent, forms of exploitations. In some cases the court seems to have struggled to bridge the differences between the two systems. ${ }^{94}$

VOL. 2, NO. 1, (April 1995) (arguing that copyright laws cannot protect designs that have been around for several hundreds of years and can therefore be considered as a part of the prior art).

89. See Dieter Dambiec, The Indigenous People's Folklore and Copyright Law (visited Feb. 19, 2001) <http:// ozemail.com.au>.

90. See Jacoby, supra note 70.

91. See Bulun Bulun v. Nejalm Pty Ltd, Golvan, E.I.P.R. 346 (1992).

92. See id.

93. Yumbulul v. Reserve Bank of Australia, 21 I.P.R. 481 (1991).

94. See Milpurrurru v. Indofurn Pty. Ltd., 30 I.P.R. 209 (1994). Case 
Professor Long argues that fixation and identification of the author are the concerns preventing the use of copyright law for protecting folk material. ${ }^{95}$ She concludes that fixation is not a mandatory requirement under TRIPS, and highlights the "work for hire" concept as evidence that the standards in modern copyright law have expanded the strict definition of an author. $^{96}$ This is a practical approach for ensuring immediate protection until a sui generis system is established. Copyrights can still be easily infringed expanded definition of author. However, this will be a beginning and is infinitely better than no protection at all. The issue whether this can be a permanent solution is arguable and needs more in-depth study.

In addition to fixation and identification of the author, copyright law requires "originality," "97 which will not protect folk art as it will fall within public domain. Copyright cannot be vested over the entire tribe or community as the law does not recognize community ownership. ${ }^{98}$ Lastly, copyright will not recognize any form of perpetual protection that is needed to protect the originality of the folk materials. ${ }^{99}$ One option is to consider and give primacy to customary rights. Certainly this should be considered in a dispute involving indigenous people. Interestingly, customary laws distribute rights fairly within the community. Ownership of designs or imagery is vested in the clan, and the right to use or make and sell a work or create a facet of the work is vested within certain members of the clan. These rights can only be inherited or gained by reputation. ${ }^{100}$ The Maori society in New Zealand is one example of a society

discussed in detail in Part V.

95. Doris Estelle Long, The Impact of Foreign Investment on Indigenous Culture: An Intellectual Property Perspective, 23 N.C. J. INT'L L. \& COM. REG. 229 (1998).

96. See id. (arguing that work for hire concept, which is also recognized by TRIPS, is a classic example to prove the dilution of the need for originality or intellectual creativity for copyright protection). Professor Long also argues that copyright laws should protect traditional knowledge by carving a similar exception. See id.

97. See Dambiec, supra note 86.

98. See also, Blankley supra, note 88. (arguing that protection through copyrights is inadequate and that there is a need for a sui generis form of protection).

99. See generally Lucy M. Moran, Intellectual Property Law Protection for Traditional and Sacred "Folklife Expressions"-Will Remedies Become Available to Cultural Authors and Communities?, 6 U. BALT. INTELL. PROP. L.J. 99 (1998).

100. See id. 
that managed property through customary rights. ${ }^{101}$

\section{Trademarks and Geographical Indicators}

Trademarks and geographical indications are used to provide a link between the customer and the manufacturer of the goods. It helped identify the place of origin of the goods. ${ }^{102}$ The protection of the customs and art of indigenous people by this area of law is yet to be exploited. ${ }^{103}$ Interestingly, geographical indicators or trademarks can be used as mechanism for the protection of some forms of indigenous art. For example, a trademark or a geographical indication can be an indicator for a particular tribe or indigenous group, thereby identifying the tribe or group to the consumer. The Lisbon

101. See id. The Maori Society manages the use of cultural and creative works on a differentiated basis so that control and use is distributed over several levels.

This ranges from a chief (ariki) who is considered as the guardian of tribal (iwi) interests, followed by minor chiefs acting as "custodian trustees" within sub-tribes (hapu) in relation to various subordinate and collective affairs, and then extended family (whanau) and individual property rights. Individual rights are qualified by an over-sight of the community to use property to serve wider needs. The defined bundle of privileges and obligations that exists is similar to a process of delegated authority. The system holds together because of the tribe's close social bonding and the imposition of supernatural restrictions (through concepts such as "sacredness" or tapu prevalent in Maori society) which govern how certain works or techniques can be used for different purposes or ceremonial occasions. While this may prohibit undue departure from traditional usage, it also ensures the retention of recognized standards and emotional attitudes towards the use of a work or its adaptation. In this sense the tribe's moral concern with the work is strengthened which in turn reinforces the communal ownership of the work.

Id.

102. See G. S. Srividhya, Overview to the Law of Trademarks in India, Intellectual Property for the Pharmaceutical Industry (visited Feb. 17, 2001) $<$ http:// www.iprlawindia.org/law/contents.trademarks/ articles/tmart.html>.

103. See Downes supra, note 15. Downes asserts that this area has not been used as a mechanism for intellectual property protection and since it is only the possibility of protection within the patent law that has been examined. See id. Professor Downes asserts that the geographical indicators are especially suitable since they are based upon collective traditions and a collective decision-making process; they protect and reward traditions while allowing evolution; they emphasize the relationships between human cultures and their local land and environment; they are not freely transferable from one owner to another; and they can be maintained as long as the collective tradition is maintained. $I d$. 
Convention, 1958, ${ }^{104}$ recognizes geographical indicators ${ }^{105}$ and provides for a system of international registration. ${ }^{106}$ The Madrid Convention, 1891, ${ }^{107}$ provides for registration of trademarks. Both of these agreements have been recognized under TRIPS. ${ }^{100}$

The mark or the indication can be used to refer to a tribe, an artist, or a combination of both. This also has the flexibility to be used for all forms of folk art, including folk medicines. Geographical indications are not author specific nor do they require an element of innovation. Like trademarks, they are meant to protect the producers or the manufacturers of goods. Geographical indications are also better for echoing the communal sense, as it is based on its location and method of production. It is immaterial whether the producer is an organized corporation or whether he is a single individual. ${ }^{109}$ Typically, the producers based in the relevant region can work together to establish, maintain, and enforce guidelines for protection of the geographical indication. ${ }^{110}$

\section{Trade Secrets}

Trade secret law is possibly the best form of protection for the traditional knowledge amongst the prevailing regimes of intellectual property. A trade secret can consist of any pattern, device, compilation, method, technique, or process that gives a competitive advantage. In corporate terms, even items or data such as customer lists, financial information, recipes for food or beverage products, technical subject matter of a patent, marketing procedures, or a professional questionnaire can be

104. Lisbon Agreement for the Protection of Geographical Indicators and the Appellations of Origin and their International Registration, October 31, 1958 as amended in September, 1979.

105. Article 2 of the Convention defines appellations of origin as "the geographical name of a country, region, or locality, which serves to designate a product originating therein, the quality and characteristics of which are due exclusively or essentially to the geographical environment, including natural and human factors." Id.

106. Article 5 of the Convention gives the details of international registration with the international bureau. See id.

107. Madrid Agreement Concerning the International Registration of Marks, April 14, 1891 as amended in 1979 (providing for the establishment of a special union for the registration of marks).

108. See TRIPS, supra note 19.

109. Downes, supra note 15.

110. See id. 
protected by trade secrets. For example, trade secrets can vest an implied duty on a photographer not to sell or exhibit copies of a photograph without the consent of the photographed. ${ }^{11}$ Trade secrets is also the best form of intellectual property for protecting any kind of undisclosed information. ${ }^{112}$ The object is to lawfully prevent information (which is a secret having commercial value) within the control of a person from being disclosed to, acquired by, or used by others without consent, in a manner contrary to honest commercial practices. ${ }^{113}$ The reasonable person test is used to determine whether there has been any misuse of the information. ${ }^{114}$

The first step towards trade secret protection of the knowledge of the indigenous people is the realization of its value by the holders. The awareness of the rights and long term benefits that will be gained if protected as a trade secret is also essential. Normally, knowledge limited to and secured by an identifiable number of people is subject to trade secret protection provided there is a clear intention to treat it as a secret. Corporate trade secrets have been protected by welldrafted agreements with specific employees in a department, or the entire company may have knowledge of the confidential information.

There are instances where indigenous people have also tried to adopt the same strategy. For example, a small tribe in Peru adopted this methodology to protect its property from the California based Shaman Pharmaceuticals Inc (hereinafter Shaman). ${ }^{115}$ Shaman is a company based in San Francisco. It focuses on isolating bioactive compounds from tropical plants having a history of medicinal use. The company's research team collects information on the use of plant medicines to treat various illnesses. Shaman, as a part of its program, approached a particular tribe in Peru. The tribe/community

111. See Geetanjali Lakotia, Trade Secret Laws: Do We Need Them in India - A Comparative Analysis (visited Feb. 17, 2001) $<$ http://www.iprlawindia.org/law/contents/. . .ts/Articles/trade_sec_laws_glakh otia.htm>.

112. See TRIPS, supra note 26.

113. See TRIPS, supra note 26.

114. See Lakotia, supra note 111.

115. See Donald E. Bierer, Thomas J. Carlson, and Steven R. King, Shaman Pharmaceuticals: Integrating Indigenous Knowledge, Tropical Medicinal Plants, Medicine, Modern Science and Reciprocity into a Novel Drug Discovery Approach (visited Feb. 19, 2001) <http://www.netsci.org/science/ special/feature11.html>. 
demanded that they enter into an agreement with the company to get short and long-term benefits. The terms in the agreement addresses reciprocity from the company to the tribe in three stages. The short-term reciprocity addresses immediate needs of the community, like public health, forest conservation, and medical care. The medium-term reciprocity consists of benefits not immediately apparent, but nonetheless provides benefits before profit sharing might. These include providing equipment, books, and other resources. The longterm reciprocity involves returning a portion of the profits to the indigenous communities once a commercial product is realized.

However, the company does not share the patents or part of the proceeds from the patents with the indigenous people who provided the initial material. Long-term benefits will accrue in absolute terms only from intellectual property rights and not from the facilities that may be provided to the tribes. Nevertheless this is a good beginning. It will not be long before the indigenous people refuse to sign the dotted line unless the intellectual properties are shared.

\section{a. The Trade Secrets, Biodiversity and UN Triangle}

Protection as a trade secret is cheaper, quicker, and easier to implement than a patent. A trade secret can also be maintained perpetually, unlike other forms of intellectual property. The legal requirements for proving that a trade secret exists are more flexible than that for obtaining other forms of intellectual property like a patent. Information not susceptible to patent or copyright protection can be protected under trade secrets. ${ }^{118}$ Infringement like using information ${ }^{119}$ without permission of the community can be effectively prevented by suing for misappropriation of trade secrets, benefiting the community.

\footnotetext{
116. See id.

117. See id.

118. See Lakotia, supra note 111 .

119. See id.
} 
b. The Trade Secrets, Biodiversity and UN Triangle

There is also an additional benefit in deciding to protect the knowledge as a trade secret. If traditional knowledge is a trade secret, the holders will retain the right to decide whether or not to disclose the information. However, the Convention on Biodiversity, 1992 (CBD) mandates sharing of genetic resources for the benefit of general good subject to prior informed consent. ${ }^{121}$ It will be interesting to see whether the rights under trade secret law will prevail over the obligations under the CBD. On the other hand, the UN Draft Declaration on the Rights of the Indigenous People ${ }^{122}$ (hereinafter, UN Declaration), provides for the right to protect cultural property. Under the prevailing intellectual property regime, an inventor cannot be forced to disclose his invention under patent law, nor can an author be forced to publish his work under copyright law. Applying the same analogy, the indigenous people must also be given the right to keep their knowledge a secret. It will be interesting to see whether the rights of trade secrets and those detailed in the UN Declaration must prevail over the CBD.

\section{Protection by a Combination of Existing Intellectual Property Rights}

Various authors suggest a comprehensive protection for traditional knowledge by evolving new theories within the existing intellectual property regime. Professor Long suggests the use of moral rights to acknowledge the source of a work and to protect the integrity ${ }^{123}$ of traditional knowledge. ${ }^{124}$ This is similar to Professor Gopalakrishnan's obligation theory: "The owner of a new product based on traditional knowledge while claiming intellectual property protection must have the

120. U.N. Doc. Biodiv Na 92-7807 (visited July 15, 2001) $<$ http://www.biodiv.org>.

121. See id. at Article 15 (discussing access to genetic material).

122. The United Nations Draft Declaration on the Rights of Indigenous People, 1993, as agreed upon by Members of the Working Group in the 11th Session.

123. This right is recognized under the Berne Convention for the Protection of Literary and Artistic Works. The Berne Convention was established September 9, 1886 and entered into force on December 5, 1887. See 331 U.N.T.S. 217.

124. See supra note 95 . 
obligation to disclose to the community from where the knowledge was taken and also give evidence as to the prior informed consent." 225

Professor Downes favors the use of moral rights and suggests that this concept should be a model to enable recognition of the works of traditional people. ${ }^{126}$ However, the question of whether a specified alleged reproduction of work is a violation of moral rights is likely to become subject to the court's predilections and preconceived notions. However, for the short-term, a combination of moral rights and copyrights, coupled with trademarks and geographical indicators can provide overlapping rights. For example, a folklore can have a geographic indicator indicating the region of origin. It may also have a trademark as a mark of the tribe, group, or sometimes as a mark owned by the artist. The song, lyrics and tunes can also be protected under moral rights. Attempts to remix a song and other forms of tampering can be brought as violations under moral rights theories or under trade secret law. In addition, one or more of the following can be applied to ensure added protection:

1) Deterrent punitive measures such as sharing a percentage of the profits could be incorporated. These would be mandatory obligations on the infringers to adequately compensate the indigenous community. ${ }^{127}$

2) Unauthorized information holders could be banned from commercializing on patents acquired from traditional knowledge without acknowledging the source. The CBD and other Conventions can be amended to incorporate such a sanction. This method could deter the multinational corporations from seeking to obtain cheap information from the indigenous people.

3) Indigenous people could be made joint owners of the intellectual property rights created from their knowledge. The Shaman Pharmaceuticals case can be used as a model for agreements between corporations and indigenous people. However, the measures should also include the mandatory sharing of patents as joint inventors.

125. Dr. N. S. Gopalakrishnan, Protection Of Traditional Knowledge - The Challenges (Paper presented at the WIPO Conference held at Peking University, Beijing, June 15, 1999).

126. See supra note 15.

127. See supra note 116 . 
4) In the case of a legal dispute, the burden of proof should be on the user of the knowledge to show that valid consent was obtained from the community. ${ }^{128}$ These obligations must be built into TRIPS to make it effective and operative.

5) Patent statutes should incorporate an affirmative defense provision. For example, a person accused of infringing a patent could argue that that the product or process in question was derived from traditional knowledge of a specified indigenous people and that he will include them as joint inventors. Alternately, a third party should be allowed to invalidate a patent on the ground that the product or process in question was invented through the use of traditional knowledge without permission. ${ }^{129}$ This will strengthen the bargaining power of the developing countries while negotiating with multinationals who need their traditional knowledge.

\section{Sui generis System}

Sui generis rights are alternate models created outside the prevailing intellectual property regime. Protection by such sui generis rights has been considered as an option to protect plant variety and traditional knowledge, though very little has evolved on account of the nature of the property sought to be protected. Article 27.3 of TRIPS allows countries to exclude plants and animals from patenting. This clause also provides protection by sui generis systems. The issue, however, is that the contours of sui generis rights are unclear and the mechanism for enforcement uncertain. Moreover, whether developed nations and the WTO will agree to rights that are defined by individual countries remains a question. Given that developed nations use trade sanctions to force countries to tune in with TRIPS, ${ }^{130}$ it is uncertain whether a flexible right will be

128. See id. See also supra note 92.

129. This mechanism is favored by Professor Gopalakrishna (he does not favor the validation of the patent using traditional knowledge). See supra note 125 .

130. For example, the U.S. complained that Argentina's new patent law delayed extension of patents to pharmaceuticals until the year 2000 - even though developing countries do not have to phase-in patent protection of new product types under TRIPS until a total of ten years after TRIPS enters into force, which is well after 2000. See supra note 19. Similarly, in India, the Patent Second Amendment Bill has a provision that is similar to the polar provision of the U.S. (The stockpiling exception states that before the expiration of the patent, a third party cannot pile up his stock so that he can enter the market as soon as the patent holder's term expires.) The U.S. is 
acceptable. The extent of flexibility will depend on whether the western intellectual property system can accommodate rights that are not beneficial to local industries. The International Seminar on Sui Generis rights ${ }^{131}$ records that:

[D]eveloping and least developed countries are looking at sui generis clause as a window, an opening, to enact legislation that goes beyond IPR for protecting rights of vast majority of their citizens - farmers, healers, indigenous and local communities who apply creative intellectual efforts and develop useful technologies with bio diversity and their knowledge of the same. Going beyond IPR is not prohibited by TRIPS. What is unknown is how sui generis laws that go beyond IPR, providing rights that are different from IPR, will function in a world increasingly dominated by IPR - and how WTO will react to it. It is important to note that in many countries the discussion on rights related to biodiversity for grassroots communities is not linked to TRIPS and therefore many Latin American countries that has notified WTO of their plant variety protection laws to comply with the sui generis option, are working towards a legislation with broader rights to deal with plant varieties as part of bio diversity. ${ }^{132}$

Professor Santasombat advocates the use of a sui generis system similar to the common property regime to ensure adequate protection to the people concerned. ${ }^{133}$ Dr. Williams, ${ }^{134}$ on the other hand opines that sui generis rights could result in the watering down of community rights. He discusses the option of a single alternate system, or a system designed under TRIPS or CBD individually, or a combination of both. The International and other Conventions do not seem to disfavor

seeking legislative intervention to prohibit the approval of a generic version of the local drugs before the expiry of the term of the patent. Typically, the implication is that before a generic version is approved, the original patent holder, which is more often a U.S. multinational, will get to be the exclusive seller in the market for a period of easily three to four years.

131. International Seminar on sui generis Rights, RESOURCE UPDATE (Thai network, Bio Diversity and Genetic Resources Action International, Bangkok) 8, December 1997.

132. SIGNPOSTS TO SUI GENERIS RIGHTS (December 6, 1997) $<$ http://www.grain.org/publications/signposts.htm>. (This was also used as a resource material for the international seminar on sui generis rights.)

133. See Yos Santasombat, History of a Struggle, SIGNPOSTS TO SUI GENERIS RIGHTS (December 6, 1997) <http://www.grain.org/publications/ signposts.htm>.

134. Dr Owain Williams, Sui generis rights - A Balance Misplaced, SIGN POSTS TO SUI GENERIS RIGHTS, at <http:/www.grain.org>. 
sui generis rights, but have not even adopted a definition of the same yet. Even the ever meticulous TRIPS allows for the protection of plant varieties by an effective sui generis system without defining what a sui generis system is. TRIPS however, hopes that the developing countries will have an effective sui generis system by January 2000 and the least developed countries by January 2006. The word effective has also not been defined. ${ }^{195}$ It is as if the world bodies have decided that this problem does not require attention beyond the grant of recognition. It is now left for the indigenous people to decide the modus and the laws in which they would like to protect their knowledge.

\section{INTERNATIONAL CONVENTIONS, INTERNATIONAL BODIES, AND DECLARATIONS BY THE INDIGENOUS PEOPLE}

This part discusses the various international conventions, and the efforts made by international bodies like WIPO and UNESCO. This part also includes the Declarations made by the indigenous people themselves to protect their knowledge. The object is to trace the slow recognition of the rights of these people, focusing particularly on their intellectual property issues. This part evaluates the various attempts critically and highlights that none of the efforts have produced satisfactory results.

\section{A. INTERNATIONAL CONVENTIONS}

1. Recognition of Indigenous People on an International Level

The first attempt internationally to protect the rights of the indigenous people began when the International Labor Organization (ILO) convened a Conference Concerning the Protection of Indigenous and Other Tribal and Semi-Tribal Populations in Independent Countries, 1957. ${ }^{136}$ This was the first conference to attempt to promote better social and economic conditions for the indigenous populations. However, it "does not envisage a place in the long term for robust, politically significant cultural and association patterns of

135. See supra Part II.A.6.

136. Conference No. 107 of the ILO. 
indigenous groups." They are considered very secondary and as a mere beneficiary of rights and protections. ${ }^{137}$ The ILO Convention No. 169, Concerning Indigenous and Tribal Peoples in Independent Countries, 1989, revised this Convention. ${ }^{138}$ The revised Convention is the first (and to date, the only international treaty) to define 'indigenous people'. It defined the indigenous people as those who inhabited a country or area within a country at the time of conquest, colonization, or the establishment of present state boundaries, and who, "irrespective of their legal status, retain some or all of their own social, economic, cultural and political institutions." ${ }^{139}$ The Convention sought to protect the prevailing systems in these societies and presumes that these people are, in most cases, not able to speak for themselves or take part in the decisionmaking process that affects them. It asserts that they have the right to take part in this decision-making process, and that their contribution will be valuable to the country in which they live. ${ }^{140}$

This Convention is almost apologetic in adding that, although the earlier Convention (No. 107) intended to provide protection, it assumed that the problem of indigenous and tribal populations would disappear with the gradual integration of these peoples into the societies in which they lived and assures that the present Convention seeks to protect the prevailing systems and identities of these societies.

Neither of the ILO Conventions addressed issues relating to intellectual property protection. Article 13(1) of Convention No. 169 urges the Government to respect the collective aspects of the relationship in these societies. This was the first time that something close to community intellectual property

137. See supra note 13 at 44 .

138. The general background of the Convention traces the activities of ILO vis-a-vis the indigenous people and states that

[t]he ILO was active in the early 1920s investigating the forced labour of so-called 'native populations' in colonies. Indigenous and tribal peoples were, by definition, part of this colonial work force, and the same impulse that gave rise in 1930 to the Forced Labour Convention No. 29, led to standards and development work on indigenous and tribal peoples.

\footnotetext{
International Labour Organization (visited Feb. 21, 2000) $<$ http://www.ilo.org $>$.

139. See id.

140. See International Labour Organization (visited Feb. 21, 2000) $<\mathrm{http}: / / \mathrm{www}$.ilo.org/papers.htm>.
} 
protection was mentioned. ${ }^{141}$ Now, several international, as well as national communities are considering the possibility of recognizing and providing community intellectual property protection.

\section{Emergence of IPR issues in International Conventions}

The issues relating to intellectual property protection of traditional knowledge emerged when multinationals obtained commercial benefits from knowledge that was predominantly within local control for multiple generations, and was long presumed to be in the public domain of the respective indigenous communities. The first notable development was the United Nations Conference on Environment and Development (The Rio Earth Summit), 1992. ${ }^{142}$ Chapter 26 of Agenda 21 of the Rio Declaration is devoted to recognizing and strengthening the role of indigenous communities. ${ }^{143}$ It outlines the historical relationship of the people with the land, and the need to have freedom to enjoy the lands, natural resources, and environment without hindrance. This Convention adds that its goals and that of the ILO Convention are similar and that those goals should also be incorporated into the UN draft Declaration thereby establishing a uniform objective. It calls for participation and encouragement at all levels from the communities, and urges the Government to call for such participation.

Important issues relating to the indigenous people and preservation of property was taken up in the Convention on Biological Diversity, 1992, ${ }^{144}$ which desired to enhance and compliment existing international arrangements for the conservation of biological diversity. It determined to use the

141. The Convention on the Means of Prohibiting and Preventing the Illicit Import and Export and Transfer of Ownership of Property, 1970, addressed issues relating to cultural property and mentions the protection of flora and fauna, though, today the Convention protects properties of archeological importance. This Convention did not make any significant changes vis-a-vis the intellectual property rights or traditional knowledge.

142. See U.N. Doc. A/CONF/151/26 VOL IV, available at United Nations Environment Programme (visited Feb. 21, 2000) <http:// www.unep.org>.

143. Chapter 26.4 (b) states that governments should "adopt or strengthen appropriate policies and/or legal instruments that will protect indigenous intellectual and cultural property and the right to preserve customary and administrative systems and practices."

144. See U.N. Doc. Biodiv. No. 92-7807, available at Convention on Biological Diversity (visited Feb. 21, 2000) <http://www.biodiv.org>. 
same for the benefit of mankind and for the present and future generations. $^{145}$ Article $8(\mathrm{j})$ emphasizes the approval and the involvement of the tribes. ${ }^{146}$ Article 15 specifies that prior informed consent of the indigenous people is mandatory, ${ }^{147}$ and Article 17 mandates the States to facilitate exchange of information. This Convention established that the resources that were concentrated with one or more societies ought to be used for the benefit of mankind. However, this Convention neither refers to the ILO Conventions, nor does it incorporate the definitions of "indigenous people" from the ILO Convention.

The UN came up with a Draft Declaration On the Rights of Indigenous People, 1981. ${ }^{148}$ It constituted a working group on indigenous people ${ }^{149}$ and set out the "minimum standards for the survival, dignity and the well being of the indigenous people." It asserted their right to full and effective enjoyment of all human rights and fundamental freedoms and reiterated the right of self-determination for these people. ${ }^{151}$ Article 4 asserted that the indigenous people "have the right maintain their distinct political, social and cultural characteristics as well as their legal systems while retaining their right to participate fully, if they choose to, in the political, legal life of the State." 152 Article 12 recognized the right to practice and

145. Broadly, these were the main objects of the Convention.

146. Each Contracting Party shall, as far as possible and as appropriate,... (j) Subject to its national legislation, respect, preserve and maintain knowledge, innovations and practices of indigenous and local communities embodying traditional lifestyles relevant for the conservation and sustainable use of biological diversity and promote their wider application with the approval and involvement of the holders of such knowledge, innovations and practices and encourage the equitable sharing of the benefits arising from the utilization of such knowledge, innovations and practices.

Art. 8(j) of the CBD, In Situ Conservation (emphasis added).

147. In so doing, this Convention has become one of the only two Conventions that includes the concept of prior informed consent. Convention on the Control of Trans-Boundary Movement of Hazardous Waste and Their Disposal, 1989, also deals with prior informed consent.

148. See U.N. Doc. E/CN.4/SUB.2/RES/1994/45. See also The UN Refugee Agency (visited Feb. 21, 2000) <http://www.unhcr.ch>.

149. It was supported by the indigenous people by the Indigenous People's Earth Charter (Article 3).

150. See supra note 148 .

151. Art. 1 of the Draft Declaration on the Rights of Indigenous People (which is divided into 9 parts and has a total of 45 Articles).

152. See id. (emphasis added). 
revitalize their cultural traditions and customs. ${ }^{153}$ Article 19 asserted their right to participate, if they choose to, at all levels of decision making through "procedures determined by them"154 and the right to determine their own strategies for exercising their right to development. ${ }^{155}$ Article 24 described right to their traditional medicines and health practices including the right to protection of vital medicinal plants, animals and minerals. Article 26 discussed the right to "effective measures by the State to prevent any interference with, alienation of, or encroachment upon these rights." ${ }^{156}$ Article 29 recognized full ownership, control and protection of the cultural and intellectual property of indigenous people. ${ }^{157}$ The intellectual property vested with the indigenous people was classified into folklore and crafts, biodiversity, and indigenous knowledge by the Report of the Secretary General of the UN in 1992. ${ }^{158}$ In 1993, the Working Group on Indigenous Populations accepted the Draft Declaration On the Rights of Indigenous People.

The Trade Related Intellectual Property Rights System (TRIPS), $1994^{160}$ was the next major international development. Unfortunately, the World Trade Organization did not find it fit to include aspects relating to protection of traditional

153. This includes the right:

to maintain, protect and develop the past, present and future manifestations of their cultures, such as ....artefacts, designs, ceremonies, technologies and visual and performing arts and literature, as well as the right to the restitution of cultural, intellectual, religious and spiritual property taken without their free and informed consent or in violation of their laws, traditions and customs.

Id. at Art. 12.

154. See id. at Art. 19.

155. See id. at Art. 23.

156. See id. at Art. 26.

157. Indigenous People are entitled to the recognition of the full ownership, control and protection of their cultural and intellectual property. They have the right to special measures to control, develop and protect their sciences, technologies and cultural manifestations, including human and other genetic resources, seeds, medicines, knowledge of the properties of fauna and flora, oral traditional, literatures, designs and visual and performing arts.

Id. at Art. 29.

158. See Intellectual Property of Indigenous Peoples: Concise Report of the Secretary-General, E/CN.4/Sub.2/1992/30 (July 1992).

159. Draft Declaration as agreed by the Members of the Working Group of the United Nations at its Eleventh Session (August, 23, 1993).

160. See supra note 19. 
knowledge in TRIPS. On the one hand the importance of enforcing intellectual property rights to grant justice to the multinationals to ensure equal treatment was emphasized. On the other hand, that the knowledge of the indigenous people is being misused has been totally ignored. Considering that it is the western scientists who invent and multinationals which invest, the human rights perspectives in developing countries and the miseries on account of increased drug prices amounting to dying populations were totally ignored. ${ }^{161}$ The indigenous people felt that the different set of logics and laws were applied to the art and the works of the indigenous people.

\section{B. The Conventions - A CRITIQUe}

\section{Reverse Determination}

It is interesting to note that CBD's objective to share the resources of the world arises at a time when these resources have become valuable. The Convention does not address the benefits to either the Community or the individual holders respectively. The technology transfer clause in the CBD is incomplete for want of modus. The cost to the community in having to share such information has not been detailed. The benefit the community would derive, if at all, from such sharing is unclear from Articles 15 and 16. This Convention does not incorporate the reverse determination, which is a mandatory declaration that the indigenous people should be compensated by vesting intellectual property or its equivalent rights over the knowledge acquired from them. Strangely, the CBD expects that resources are to be shared for the benefit of 'mankind' and that the most downtrodden societies of the world should enable the benefit.

161. The argument of the developing countries is that when the regime changes from process patent to product patent, some of the lifesaving drugs for which the developing countries have found new processes through reverse engineering and are therefore available at low costs will not be available at the market anymore. As a consequence, in countries where the poverty level is high, there will be a considerable section of the population that will not get access to lifesaving drugs. 


\section{Prior Informed Consent}

Prior informed consent is a concept detailed in the CBD to ensure that the consent of the indigenous people is received before the resources are shared. It is unclear whether the indigenous people should be informed about the possibility of taking a monopoly intellectual property right over their resource before the resources are accessed. The indigenous people may not give consent so easily if they are aware of the monetary benefits received from taking their resources. 'Prior informed consent' has not been defined under the CBD, maybe because the degree of knowledge may vary depending on the people and the material in question, not to mention the degree of understanding of the people. However, the failure to define the phrase leaves open the opportunity for misuse by the benefiting mankind. Adequacy of consent and components of "fully informed consent" will have to be clarified. There should also be emphasis on the extent of information to be provided in order to get the consent.

Interestingly, the UN Declaration discusses free and informed consent. However, there is no definition of what amounts to a "free" and "informed" consent. It is unclear if the information should relate to the potential future commercial benefits to the user of the knowledge or the potential benefits of continuing to keep the knowledge a secret. In a community setting, free consent may require consent of the community. Hence the definition of free consent will eliminate issues at a later period. For example, a research from blood samples of members of Soloman Island showed a strain with immunity to a virus and gave raise to a drug for which a US Patent was applied. The indigenous people who have become aware of the market potential of the drugs were demanding compensation for the samples. The donee company argued that the blood and the spleen were given with consent. ${ }^{162}$ However, the extent of information given to the donor was never known, nor was the islanders aware of the commercial benefit the donee multinational would obtain in the future. In any case, had the donor known the full potential of his donation, he would have had a better bargaining power. The CBD has not clarified any future course of action in cases where information was not acquired with "adequate consent." Statutorily invalidating

162. See supra note 35 , at 927 . 
information when the crux of the information has already been made public or known by virtue of a patent application is neither a deterrent nor a protective mechanism.

\section{Right to Withhold Information}

The CBD on the one hand speaks about mandatory sharing of information. On the other hand, the Convention discusses prior informed consent. It is not clear which prevails over the other. If the holders of the knowledge were to refuse consent after understanding the consequences, it is unclear whether the use of the knowledge would amount to a violation of the CBD.

\section{Right Not to Disclose}

The issue whether the right to privacy includes the right not to disclose knowledge in possession has to be clarified. This also raises the question as to whether one's right to privacy can be considered violated where the knowledge was acquired and used without consent or by indirect sources.

\section{Trade Secrets and CBD}

Further clarification of the right to privacy becomes all the more important if traditional knowledge is sought to be protected as a trade secret.

\section{Legal Systems}

Interestingly, Article 4 of the UN Declaration vests the indigenous people with a right to their legal systems. It is not clear whether they can demand, in cases involving intellectual property violations, to apply their customary laws.

\section{Ownership Factors}

None of the Conventions address the ownership factor, which is important to ensure fairness in benefit sharing. Issues on benefit sharing are bound to arise where members of a community are scattered. 


\section{Unexplored Ideas}

Some of the Conventions came up with practical suggestions that were left unexplored. For example, the concept of 'community rights' first initiated at the ILO Conference was not immediately researched. Similarly, the "common goals in Conventions" doctrine of the Rio Summit has yet to be taken seriously. The "sui generis" model that was prompted by the Model Code ${ }^{163}$ (discussed later) was yet another idea that was never explored further.

\section{Special Provisions for Protection of FolKLore}

Folklore is another area that has not been protected despite several attempts. Discussions of protection of indigenous properties will be inadequate without a discussion on folklore. The following is an outline of the failed attempts to protect folklore. In 1967, the Diplomatic Conference of Stockholm, for revising Berne Convention, $1971^{164}$ resulted in the introduction of the Article 15(4) to protect folklore within copyright law. Article 15(4) states that in case of unpublished works, where the identity of the author is unknown and the author is presumed to be the national of a signatory to the Berne Union, the country shall, by legislation designate a competent authority to represent the author in the entire Union. ${ }^{165}$ The Director General shall then be notified, who shall in turn communicate the representation to the entire Union. ${ }^{166}$

Unfortunately, the Berne System still revolves around an author specific requirement. That a community can own knowledge is not yet conceptualized under the western intellectual property regime. This issue arises from the difference in the understanding of "property" as conceived by the western and the indigenous societies. The designation of an authority to protect folklore induces the feeling that the indigenous people are incapable of protecting their folklore. This same idea is reflected in all the Model Provisions on Folklore and has been specifically stated by the Working Group

163. See infra note 185 and accompanying text.

164. See Berne Convention for the Protection of Literary and Artistic Works, as revised in Paris in 1971, World Intellectual Property Organization (visited Feb. 21, 2000) <http://www.wipo.org>.

165. See id.

166. See id. 
on the Aboriginal Folklore Model. ${ }^{167}$ This reaction of trying to force western forms of courts and authorities, without appreciating local systems as well as unilaterally deciding that indigenous people need outside protection is perceived as a typical reaction from the west, which the indigenous people resist.

\section{Model Laws for Protection of Folklore}

Developing countries continued to demand that their folklore and the folk art be protected and that the developed countries stop benefiting from the lack of protection. Hence, several world bodies, particularly WIPO and UNESCO attempted to create instruments for the protection of folklore. ${ }^{168}$

The Tunis Model Law on Copyright for Developing Countries, $1976,{ }^{169}$ was the first attempt by UNESCO and WIPO to bring folklore within copyright law. ${ }^{170}$ It provides that musical works need not be fixed to enjoy protection, though artistic, literary and scientific works needs to be fixed for protection. ${ }^{171}$ Section 3 grants protection to "national folklore" as a derivative work. ${ }^{172}$ Section 4 vests the rights to reproduce and translate with the author. ${ }^{173}$ This may be difficult in case of aboriginal works where the permission of the tribe is mandatory under the tribal customary laws. ${ }^{174}$ Section 18 provides for a "competent authority," which is "one or more bodies, each consisting of one or more persons appointed by the

167. See infra note 178 (discussing the idea in detail).

168. See infra notes 169-181.

169. Tunis Model Law on Copyright and Commentary, THE CopyriGHT BulletiN, Vol. 10, no. 2, at 10 . This was drafted by the Secretariat of UNESCO and the International Bureau of WIPO with the Committee of Governmental experts convened by the Tunisian Government between February and March 1976.

170. The Tunis Model Law reflects a basic realization that the nature of folklore poses special problems for standard copyright laws. See supra note 81 .

171. It treats the "original" character of the work as a matter of fact and distinguishes between "originality" and "novelty." See supra note 169. Thus two craftsmen carving a wood figurine representing an elephant each create, although the two figurines are similar and are not a subject of novelty, both as per this law have engaged in creative activity unless the one of them has simply copied the other's work.

172. See supra note 169.

173. See id.

174. See supra note 83 (for case on the same subject). 
Government for the purpose of exercising jurisdiction under the provisions of this law." ${ }^{175}$ Section 17 mandates for a payment of royalty by the user of a work in the public domain. The royalty will be paid to an authority to use the sum to promote institutions for the benefit of authors and performers, including the creation of societies and guilders, to protect and disseminate national folklore. ${ }^{176}$ This concept is called the "Domaine Public Payant" and the sum thus collected can be used for the benefit of the art and artisans. ${ }^{177}$ Interestingly, one of the beneficiaries for the sum collected by the authorities will include the translators.

In 1981, the Aboriginal Folklore Model ${ }^{178}$ recommended the prohibition of non-traditional uses of sacred secret materials and to avoid mutilation or destruction of folklore. ${ }^{179}$ It imposed a criminal sanction for failure to pay the royalty for commercial use by third parties and establishes a Folklore Commission. ${ }^{180}$ Interestingly, the working party Report recommended the following: "[i]t would be impractical to grant a property right vested in indigenous groups as there was no right of ownership under the customary laws, and there is a danger that the community would isolate their 'folklore' from the prevailing culture." 181

The recommendation that indigenous people should not be vested with copyright maintenance is another brutal reflection of the western mistrust in the ability of these people to protect their knowledge. In any case, the model may not be very workable as it imposes on the west an induced form of intellectual property law based on the concept of ownership by

\footnotetext{
175. See id.

176. See supra note 169.

177. See id.

178. In 1974, the Commonwealth Government set up a Working Party to investigate the protection of Aboriginal Folklore. The Working Party, in its report of 1981, recommended the enactment of the Aboriginal Folklore Act.

179. See id.

180. See id.

181. However, the group also recommended that a) copyright owners should not be able to prevent indigenous groups from using traditional designs, dance or music; b) copyright and designs legislation should be altered to allow customary users to exercise their customary rights freely in relation to folklore, and not have their rights to use folklore interfered with by other copyright owners; and c) imposing criminal sanctions with respect to noncustomary use of secret/sacred materials. See Our Culture, Our Future (visited Feb. 21, 2000) <http://www.icip.lawnet.com.au>.
} 
individuals and not a community. ${ }^{182}$ The working group seemingly made no attempt to understand the concept of protection that is prevalent in these societies.

Interestingly, Article 19 of the UN Declaration provides that indigenous people are entitled to the right to make decisions at all levels. ${ }^{183}$ The recommendations of the working group only proves the lack of appreciation of the fact that customarily the indigenous people have protected their knowledge for several generations while the world bodies are still struggling with working committees for workable solutions.

In 1985, the Model Provisions for the National Laws on the Protection of Expression of Folklore Against Illicit Exploitation And Other Prejudicial Actions ${ }^{185}$ was drafted to devise protection outside copyright law for musical, verbal, and other tangible expressions of folklore. ${ }^{186}$ This deviation from copyright law is perhaps a mark of realization from WIPO and UNESCO that folklore cannot be protected under copyright law, though the doctrine of 'fair practice' could evolve for folklore and other traditional knowledge. The protection is also not limited to a specified period, making another conceptual deviation from copyright laws. ${ }^{187}$

The Tunis Code and the Model Code provide for three main forms of protection that is not available under copyright systems recognized by TRIPS. ${ }^{188}$ The first is the exclusion of a time limitation for protection. The term of copyright system protection is for a minimum of 50 years (Article 12 of TRIPS). Under both the codes the protection is not limited to a time period and is perpetual. ${ }^{189}$ Second, is the exemption of folkloric

182. See id.

183. This will include the right to decide whether folklore will have to be protected by the prevailing intellectual property laws including as a trade secret and isolate it from the rest of the society.

184. See supra note 161 .

185. This is a Model recommended for the individual states. The provisions were the result of three meetings of experts convened jointly by WIPO and the UNESCO. So far, the only country that has drafted an Act for the purposes covered by the Model Provisions is Philippines.

186. It prohibits the unauthorized use of expressions of folklore, misrepresentation of the source of expressions of folklore, and willful distortions of expressions of folklore in a way prejudicial to the interests of the relevant community.

187. See id.

188. See id.

189. See id. 
works from the requirement of fixation. Copyright is available only for works that are fixed. The Codes make an exception to this requirement and provide for protection for works that are not fixed. One of the major stumbling blocks for the protection of the folkloric material is the lack of fixation. The codes seek to eliminate this. Finally, there is the introduction of moral rights to prevent the destruction and desecration of folkloric works. Since there can be no authorship over knowledge in the public domain in the community, moral rights have been introduced based on identification of the source of the work. ${ }^{190}$

Similar to the Tunis Code, Section 9 of the Model Provisions establishes a "competent authority" and a "supervisory authority" to protect folklore. Prior authorization for the use of the folkloric material in public domain is required from the competent authority (by making a written request and paying a fee), whose office is assumed to represent the relevant community's interest in protecting their folklore. ${ }^{191}$ The concept of a competent authority has its origin in the Berne Convention, 1958, but it is unclear why the holders of the property cannot be vested with the right to manage it. In any case, the idea of a designated authority defeats the purpose of the Codes and takes the right of protection from original owners by vesting it in third parties not associated with the folklore. This presents the danger of either isolating the indigenous people, or pulling them into the mainstream leading to the destruction of the traditions. Where the concerned authority is not a part of the indigenous community, it is unlikely that he will share the ethos for protection. Such an appointment will violate the right to preservation of their traditions granted to the indigenous people under the U.N. Declaration.

Lastly, it was the continued efforts of UNESCO and WIPO to bring some organization to this area ${ }^{192}$ which resulted in the

190. Joseph Wambugu Githaiga, Intellectual Property Law and Protection of Indigenous Folklore and Knowledge, E. LAW, Vol. 5, No. 2 (June 1998).

191. Such permission shall not be required under certain specified circumstances under Article 4 which includes: purposes of education; by way of illustration in the original work of an author or authors, provided that the extent of such utilization is compatible with fair practice; borrowing of expressions of folklore for creating an original work of an author or authors; and, where the utilization of the expressions of folklore is incidental. See Art. 4 of the Draft Declaration on the Rights of Indigenous People.

192. In 1997, the UNESCO-WIPO World Forum on the Protection of Folklore was organized in Thailand. In 1998, WIPO convened a Roundtable Conference on Initiatives for the Protection of Rights of Holders of Traditional 
Roundtable conferences. In 1999, WIPO organized a Roundtable in Geneva, ${ }^{193}$ where "as a specialized agency of the UN" it took responsibility for promoting intellectual property issues, particularly, traditional knowledge. The expression 'traditional knowledge' was adopted as being more appropriate after CBD. The notable aspect, however, was the statement issued by the leaders of the indigenous groups after the deliberations of the meeting. This was a response to the meeting and reflected the leaders' increased uneasiness with the world bodies by protesting that the agenda emphasized the implementation of WIPO treaties more than the intellectual property issues of traditional knowledge. ${ }^{194}$ The note called for a regulatory and a documentary mechanism and an amendment of Article 27.3(b) of TRIPS so that use of biological resources need not be mandatory, and a ban all over the world for the patenting of life forms. ${ }^{195}$ It criticized the deliberations of the meetings "that intellectual property rights as embodied in the existing international conventions and the TRIPS of WTO" and requested the world bodies to keep a more open mind. $^{196}$ (Interestingly, the discussion on the study of folklore in Central America and Panama revolved only around the general signing status of the Paris and the other Conventions before discussing protection of traditional knowledge. $)^{197}$ In 1999, the WIPO- UNESCO Regional Consultation on Folklore, ${ }^{198}$ highlighted the need for government attention and protection through a sui generis mechanism. It was agreed that a standing committee on traditional knowledge and

Knowledge, Indigenous People and Local Communities where the need to understand indigenous people was stressed.

193. Protection of Intellectual Property and Traditional Knowledge - A Global Issue, World Intellectual Property Organization (visited Feb. 21, 2000) $<$ http://www.wipo.org $>$.

194. See id.

195. Martin Khor, Indigenous People Criticize WIPO Approach, Pan Asia Networking (visited Feb. 21, 2000) <http://www.panasia.org.sg/twn/wipo.htm> (appearing first in the South-North Development Monitor (SUNS) of which Chakravarthi Raghavan is the Chief Editor).

196. See id.

197. See id.

198. WIPO-UNESCO Regional Consultation on Folklore, World Intellectual Property Organization (visited Feb. 21, 2000) <http://www.wipo.org>. WIPO and UNESCO have commissioned several fact finding missions. Between 1998 and 1999 there have been nine fact finding missions to various parts of the world. These missions have been to South Pacific, Southern and Eastern Africa, South Asia, North America, Central America, West Africa, Arab Countries, Caribbean, and South America. 
folklore will be established to provide legal and financial assistance. $^{199}$

The various Declarations reflect that since 1976 (when WIPO and UNESCO began to work for the protection of traditional knowledge), there has been very little change, even in the ideologies, despite the several studies conducted. Meanwhile, a considerable amount of knowledge has been plundered, and also lost, due to lack of protection. Even the discussions for protection through a sui generis mechanism have yielded very little. Considering that WTO has prevailed in successfully providing suffocating time frames for regulating and redefining the other intellectual property laws globally, one is left to wonder why WIPO and the UNESCO should take an indefinite time to bring out protective regimes for the indigenous people.

\section{Declarations by the Indigenous People}

These are Declarations made by the indigenous people themselves from various parts of the world. These Declarations are significant because they denote attempts by indigenous peoples to articulate their rights and to evolve a solution for themselves. Interestingly, various indigenous groups have organized across the world, during the same time periods, and seem to have independently expressed the same feelings and frustrations. For the first time, the indigenous people have shown a tendency to move away from WIPO and UNESCO and to formulate rights on their own. This is a reflection of their frustration as well as the strength. The standing of these declarations vis-à-vis the various Conventions are unclear. This is because such Declarations do not have any force of law under the prevailing legal system and hence can be safely ignored. Yet this may also signify the slow evolution of strength from "beggars to bargainers."

Notably, the first such Declaration was in 1992 . From 1976 to 1992, there was support from the indigenous people for the various working groups of WIPO and UNESCO. After 1992, there is a steady move to be self-sufficient in formulating their needs and requests. Perhaps, the wait for a solution from

199. There were four such Consultations that year which related to expressions of folklore on: a) Africa, held at Pretoria; b) Asia and Pacific, held at Hanoi; c) Arab Countries, held at Tunis; d) Latin America and Caribbean, held at Quinoa. 
the world bodies has been a little too long. Or may be, the energetic WTO has been a trendsetter in making the indigenous people seek their rights.

In the Kari-Oca Declaration and the Indigenous People's Earth Charter, 1992, the indigenous people of Asia, Africa, Europe and the Pacific owed to be united and not to be separated from their lands and traditions that binds them together. $^{200}$ This Declaration also contained the Earth Charter of the Indigenous People. Article 84 to Article 109 of the Charter deals with the "culture, science and intellectual property" issues. $^{201}$ Article 98 and Article 99 of the Charter states that the traditional knowledge has enabled these people to survive and that "usurping of the traditional knowledge has to be considered as a crime against people." ${ }^{202}$ The Charter alleges that the media and museums misused their pictures for commercial benefits and has portrayed the people as if the songs and dances alone represent their lives. In the same year, the Charter of Indigenous Tribal People of the Tropical Forest, ${ }^{203}$ was signed in Malaysia, reiterating that the people were the rightful owners to defend the cultures of tropical forests and demanding respect for their customs and traditions The Charter urges national governments to comply with various treaties and other covenants that have been signed with the indigenous peoples. It reiterates the value of their "biotechnologies" which "can make important contributions to humanity including the 'developed' countries," and sought intellectual property protection over the development and manipulation of this knowledge. ${ }^{204}$

The Mataatua Declaration on Cultural and Intellectual Property Rights of Indigenous Peoples, 1993, equated protecting traditional knowledge to the right of selfdetermination. ${ }^{205}$ Article 1 points out that the existing mechanisms are insufficient for protecting their knowledge. It

200. Resulting from The World Conference of Indigenous People in Territory, Environment and Development, Kari-Oca, Brazil, May 1992.

201. See id.

202. See id.

203. IAIP Charter, Mountain Forum (visited Feb. 21, 2000) <http://www.mtnforum.org/resources/library.htm>.

204. See id.

205. The tribes of indigenous people living in Aotearoa, New Zealand are called the Maatatua people. The Declaration is titled "The Maatatua Declaration on the Cultural and Intellectual Property Rights of Indigenous People," 1993 (visited Feb. 21, 2000) <http://www. tpk.govt.nz/mataatua.htm>. 
urges the people to define their intellectual and cultural property. It also urges the people to develop a code of ethics which external users must observe when recording (visual, audio, written) their traditional and customary knowledge. ${ }^{206}$ Article 2 asserts that the national and international agencies must understand that the cultural properties are vested with those who created them. ${ }^{207}$ It also urged the UN to monitor and take action against states whose persistent policies and activities damage the cultural and intellectual property rights of indigenous people. ${ }^{208}$ This Declaration was reiterated in the Statement issued by the International Consultation on Intellectual Property Rights and Biodiversity organized by the Indigenous Peoples of the Amazon Basin (COICA), 1994.

In the same year, the Voices of Earth Congress was organized. ${ }^{210}$ It sought a common policy by establishing a council to protect intellectual, scientific and cultural property. The Julayinbul Statement on Indigenous Intellectual Property Rights, 1993, ${ }^{211}$ followed this. This statement was issued in Australia. It asserted that the aboriginal intellectual property is an inherent inalienable right that cannot be terminated, extinguished, or taken. The statement called on Governments to review legislations and policies which did not recognize indigenous intellectual property rights. The statement also urged for the implementation of Conventions that recognized these rights. The Conference issued a Declaration reaffirming the right to self-determination and to the intellectual property rights. It condemned bio-prospecting and the exploitation of the intellectual property rights of indigenous peoples.. ${ }^{212}$ This was the first statement where the indigenous community came out openly on the probable disadvantageous position of the prevailing intellectual property regime to them. The COICA/ UNDP Meeting on IPR and Bio Diversity, $1994,{ }^{213}$ for the first

206. See id.

207. See id.

208. See id.

209. See supra note 174 .

210. Congress on "Voices of the Earth: Indigenous Peoples, New Partners, The Right to Self Determination in Practice," Dutch Center for Indigenous Peoples, Beurs van Berlage, Amsterdam, The Netherlands (Nov. 1993).

211. See Julayinbul Statement on Indigenous Intellectual Property Rights (Declaration made at Jingra, North Eastern Coastal region of Australia Nov. 27, 1993) (visited Feb. 21, 2000) <http://www.icip.lawnet.com.au/info6.htm>.

212. See id.

213. COICA and UNDP, 1994, The COICA Statement, Meeting on 
time rejected the prevailing intellectual property rights regime, ${ }^{214}$ as "legitimating of misappropriation of their knowledge, resources and culture." ${ }^{215}$ Like the Maatatua, this statement also linked intellectual property rights with the right of self-determination in Article $3{ }^{216}$ It declared that biodiversity, culture and intellectual property are concepts that mean indigenous territoriality. It reiterated that issues relating to access to resources have to be viewed from this standpoint. ${ }^{217}$ Article 9 highlighted the danger of distortion to indigenous systems in adjusting them to the prevailing intellectual property regime. ${ }^{218}$ Article 10 reiterated that patents and other forms of intellectual property rights are unacceptable to the indigenous people. ${ }^{219}$ The Statement formulated short and medium-term strategies to deal with these problems.

The short-term strategies are to evaluate the available materials to study the feasibility of a sui generis mechanism. However, the Statement was not totally dismissive of the prevailing regime. For example, Article 12 states that "there are some formulas that could be used to enhance the value of our products (brand names, appellations of origin), but on the understanding that these are only marketing possibilities, not entailing monopolies of the product or of collective knowledge."

The interest in considering and choosing the best of these practices is commendable, and reflects an inclination to ensure adequate protection in a practical, rather than an emotional manner. The medium-term strategies include training the leadership to draw up the use and legal protocol of indigenous laws.

Intellectual Property Rights and Biodiversity, Santa Cruz, Bolivia, September 30, 1994 (visited Feb. 21, 2000) <http://www.mtnforum.org/library/.htm>.

214. The Mataatua Declaration recommended a conference coordinated by the COICA (Coordination of the Organization of the Indigenous People of the Amazon) on cultural and intellectual property rights. As per this clause, a statement was issued by COICA in the International Consultation on Intellectual Property Rights and Biodiversity Conference held in September 1994.

215. Article 2 of the statement renounces the prevailing intellectual property laws as allowing multinationals to take the bio diversity, plant varieties and the related knowledge from the communities for free and vests the property rights in those who took the knowledge without providing any benefit for the community. See id. at Article 2.

216. See id.

217. See id.

218. See id.

219. See id. at Article 12. 
Lastly, the Sabah Declaration, $1995,{ }^{220}$ discusses a plan of action at the local levels to raise the level of intellectual property awareness of the communities. ${ }^{221}$ The Consultation has immediate short-term strategies to organize workshops and to seek initiatives from the various Governments to achieve their goals. ${ }^{222}$ The medium-term strategies include: intensifying the campaign against human genome project; building alliances with other organizations, including Asian organizations; and providing updates of the human genome project to the indigenous people to assist information dissemination. ${ }^{223}$

\section{E. DeClarations Made By OtHers For THe Indigenous COMMUNITIES}

Declarations made by others on behalf of the indigenous communities are important to appreciate and understand the growing support and sympathy for the indigenous people, from not only outside their community, but also from outside their respective regions. The Bellagio Declaration, $1993,{ }^{224}$ was made by professionals who shared common concerns about the impact of international intellectual property law on indigenous communities. $^{225}$ It states that the effects of intellectual property law on biodiversity (including the flora, fauna, plant varieties and the knowledge of various properties of the same), traditional knowledge, and other similar areas have been neglected and that the effects on the tribal and indigenous people have to be explored. ${ }^{226}$ It highlights the need for looking at community rights, rather than author-specific rights and states that most of the inadequacies are built into the basic structure due to a lack of understanding by the west of the concepts of traditional knowledge. ${ }^{227}$ It is particularly critical of systems built around the author paradigm, and declares that

220. The Declaration was convened as a part of the UNDP Consultations at Sabah in Malaysia.

221. See id.

222. See id.

223. See id.

224. See Statement of the Bellagio Conference, 1993, Case Western Reserve University (visited Feb. 21, 2000) <http://www.cwru.edu/affil/Bellagio.html>.

225. See id. The professionals referenced include lawyers, anthropologists, environmentalists, computer experts, literary critics, publishers, and activists.

226. See id.

227. See id. 
the author paradigm undervalues the importance of public domain. $^{228}$

Following the Bellagio Declaration, the Thammasat Resolution, 1994, ${ }^{229}$ reaffirmed the opposition to the extension of intellectual property rights to life forms, to bio-piracy and the monopolization of biodiversity-related knowledge as well as focused on a sui generis system. It sought for: a) revision of TRIPS to allow countries to exclude life forms and bio-diversity related knowledge from intellectual property; b) preventing CBD from becoming a mechanism for transnational corporations to trade in biodiversity in the name of "access" and "benefit-sharing;" and c) reinforcing the defense mechanisms of local communities from bio prospecting. ${ }^{230}$ The Declaration sought to mobilize a strong global movement engaging environmental, trade, agriculture, consumer, labor, health, food security, women's, and human rights, and all peoples' organizations in these campaigns. ${ }^{231}$

Suva Resolution, 1995, ${ }^{232}$ was passed a result of the South Pacific Regional Consultation on Indigenous Peoples' Knowledge and Intellectual Property Rights, in Fiji, and was a part of the effort by the UNDP's initiative on intellectual Property and indigenous people. The Conference was alive to the renouncing of the intellectual property laws by the recent previous Declarations. ${ }^{233}$ The Conference urged for the Declaration of the Pacific Regions to be "patent-free zones."234 Article 7 urges the strengthening of indigenous networks, and encouraged the UN and regional donors to support discussions on indigenous peoples' knowledge and intellectual property rights. ${ }^{235}$ Article 8 points out the importance of strengthening "the capacities of indigenous peoples to maintain their traditions, and encourage initiatives by indigenous peoples to

228. See id.

229. The Declaration was signed by representatives from nineteen countries and the focus of the seminar was on the protection of plant varieties by the sui generis option. This was signed by peasants, academicians, and non-governmental organizations. See Thammasat Resolution (visited Feb. 21, $2000)<\mathrm{http} / /$ www.twnside.org/title/tham-cn.org $>$.

230. See id.

231. See id.

232. Final Statement from the UNDP Consultation on Indigenous Peoples' Knowledge and Intellectual Property Rights, Suva, April 1995, Oxford University (visited Feb. 21, 2000) <http://users.ox.ac.uk/wgtrr/suva.htm>.

233. See id.

234. See id.

235. See id. 
record their knowledge in a permanent form according to their customary access procedures."

These various Declarations reflect the increased awareness of the relationship between indigenous peoples and intellectual property regimes. It shows the various forms of support that are evolving, but painfully, also reflects that there is a long way to go before the support becomes strong enough to gain adequate momentum.

\section{ATTEMPTS BY THE JUDICIARY FOR A SOLUTION}

Time and again the judiciary has tackled cases involving traditional knowledge or the indigenous people. This part highlights that the prevailing intellectual property regime is unable to accommodate and resolve issues pertaining to traditional knowledge. That the prevailing intellectual property regime is incapable of fitting the emerging issues within its mold is highlighted. This part also argues that there are inherent biases in protecting traditional knowledge. The critical issues that need to be addressed for protecting traditional knowledge that resonate throughout the cases are highlighted. This part concludes that the prevailing regime is a bastion of impotency in resolving crucial issues involving traditional knowledge.

\section{A. Australian Cases}

The Australian decisions are notable since they show a steady increase in sensitivity towards the various aboriginal communities and their art. In Foster $v$. Montford, ${ }^{237}$ the Supreme Court of the Northern Territory of Australia banned a book (Nomads of the Desert) published by an anthropologist, as it consisted of materials relating to the aboriginal group's sacred knowledge revealed to him by tribal leaders before thirty five years had passed. Though there was no confidentiality agreement, the court considered the need to protect the culture of the clan, and held that the publication amounted to a breach of confidence. This judgment is a very rare exhibition of sensitivity of the court in attempting to recognize the rights of the indigenous communities within the

236. Id

237. 14 A.L.R. 71 (1976). 
fold of the prevailing regime. That a copyright vests in the author of the book reflects the inadequacy of the prevailing system.

The most notable case in Australia is the famous Mabo judgment. $^{238}$ This case, filed in 1982, related to the issue of land use and the rights of people dispossessed of their land. ${ }^{239}$ For the first time, an Australian court recognized "native titles" (title over land granted based on customary laws) held by original inhabitants before European colonization provided inhabitants demonstrate traditional rights and occupation to the land according to customary law and that they have not been displaced from the land. However, the court added that native title could be extinguished, without compensation, by express legislative or administrative government action or simply by making grants in land which were inconsistent with continuing native title. ${ }^{240}$ (This was subjected to severe criticism.) Another case that sought to integrate the prevailing laws and customary laws was Wik Peoples $v$ Queensland, ${ }^{241}$ where the High Court decided that pastoral leases (similar to a license) and native land title could co-exist, but did not spell out the details of such a co-existence. ${ }^{242}$

The Morning Star case, ${ }^{243}$ involving an aboriginal artist, Yumbulul, highlighted the impotence of the prevailing intellectual property systems relating to the protection of traditional knowledge. It demonstrates how the courts can be crippled by their own legal theories. Yumbulul was a painter who had the authority and initiation required under customary laws to paint sacred arts of his tribe. He created five "Morning Star Pole" on commission from a company, which in turn sold the poles to five different museums. The Aboriginal Artists Agency acts as the collective society for aboriginal artists by acquiring exclusive licenses for their work, which it then sub-

238. 175 C.L.R. 1 (1992) (though it does not have a direct bearing on the intellectual property rights, this case is an example for a effort to incorporate, though reluctantly, the customary laws of the indigenous people).

239. See id.

240. Peter Boyle, The Meaning of Mabo, University of New South Wales (visited Feb. 21, 2000) <http://jinx.sistm.unsw.edu.au>.

241. 141 A.L.R. 129 (1996).

242. See $i d$. This case was severely criticized for not detailing the practical features of such a coexistence. This and the Mabo judgment though was sensitive about native rights, also showcased the difficulties of integrating and/or recognizing them within the prevailing legal system.

243. Yumbulul v. Reserve Bank of Australia, 21 I.P.R. 481 (1991). 
licenses to commercial users. The Aboriginal Artists Agency was approached by the Reserve bank, which showed interest in the Morning Star Pole. The Agency approached Yumbulul for a license and indicated that the copyright vested in the commissioning company and that there were no clauses restricting its subsequent use. Moreover, the association did not reveal to Yumbulul who the end customer was.

Later, in 1988, the Australian Reserve Bank released ten dollar currencies which had the representation of the "Morning Star." The printing on the currency was made under a sublicense of copyright in the work granted to the Bank by the Aboriginals Artists Agency Limited. Yumbulul had proof of having been misled and pressured into signing the license by deceptive means. The court, however, held that Yumbulul should have understood the terms of the agreement even though the details were not provided. The fact that there was a sub-license agreement must have made Yumbulul aware.

The court did observe that Yumbulul was not fluent in English. Unfortunately, it never examined the possibility that Yumbulul did not completely understand the terms of the agreement. Moreover, the court failed to address the duty of the Agency to make Yumbulul aware of his obligations and commitments, greater yet, when the pole was being sold to the Reserve Bank to be printed on the currency. Even if Yumbulul was wrong, that the indigenous people sought withdrawal of the Morning Star from the public was not considered as a factor by the court. The court seemed insensitive to the idea of community property rights. Under community property rights, the community has rights over the art of the community, irrespective of the author.

In the Australian Carpet Case, $1994,{ }^{244}$ an application before the Federal Court by the Aboriginal artists pleaded that makers of woolen carpets reproduced their art without permission. Evidence showed that the carpet manufacturer had seen the art and imported them into the carpets. The court held that there was a copyright infringement, but only awarded minimum statutory damages. The court reasoned that the loss was not substantial as the remedy was provided within six weeks. The courts would have most likely awarded more damages had the reproduction been that of a valued painter. Perhaps the artist was lucky that the art was copied by a

244. See Milpurrurru v. Indofurm, 30 I.P.R. 209 (1994). 
carpet manufacturer and not, say the powerful reserve bank! That the court considered evidence from aboriginal customary laws is a laudatory move. These were used to prove that only few members of the community with skill and the dexterity were permitted to reproduce the art. When such art is reproduced without authority, the punishment for the artist could include withdrawing the permission to paint.

Interestingly, the outcomes of Anglo-Saxon courts influence the rigor of aboriginal courts. This is possibly a reflection of the respect of the indigenous people for a regime they do not agree with. This respect is also visible in the COICA Statement of the Indigenous People, ${ }^{245}$ while others, who profess to accommodate various forms of legal systems, unfortunately, do not seem to have mutual respect. The Australian Carpet case is a step ahead of the Yumbulul decision, however these judgments prove that integrating the customary laws of the indigenous people into the mainframe legal system is an uphill task.

\section{B. AMERICAN CASES}

Section 102 (a), (c), (e) and (f) ${ }^{246}$ of the American Patents Act, $1952^{247}$ relates to novelty issues for patent rights. This section analyzes the criticism that the American courts are insensitive to issues relating to traditional knowledge. In Hodosh v. Block Drug Company, ${ }^{248}$ Milton Hodosh, a practicing dentist owned the rights to a patent for desensitizing toothpaste. $^{249}$ Richardson-Vicks, under an exclusive license, marketed the toothpaste under the trademark "Denquel.", The alleged infringer marketed a toothpaste containing potassium nitrate as a desensitizing agent. ${ }^{251}$ In a suit for infringement, it was contended that the Hodosh patent was invalid for lack of novelty. Eight prior art references were submitted. ${ }^{252}$ The prior art references included a toothache cure

245. See supra note 209.

246. The Section deals with "Conditions for Patentability: Novelty and Loss of Right to Patent."

247. 35 U.S.C. $\$ 102$.

248. 786 F.2d 1136 (Fed. Cir. 1986).

249. See id. at 1137.

250. See id.

251. See id.

252. See id. at 1138. 
used by the ancient Chinese that was detailed in the Grand Dictionary of Chinese Medicine and Drugs. ${ }^{253}$ It pointed to a substance having qualities of potassium nitrate as a cure for tooth sensitivity. However, the Court felt that a skilled person, "exercising reasonable diligence, would not be able to locate the prior art, given the esoteric nature of the references." ${ }^{254}$ In the Federal Circuit, the plaintiff argued that: "the ancient references should be dismissed because a person skilled in the art would find them incredible and would regard them as a quagmire of medical and dental nonsense."

The court remanded the case to consider whether the improvement claimed by Hodosh is non-obvious. The court did not consider lack of novelty, nor whether potassium nitrate is commonly used for the same purpose in China. Interestingly, the courts seemed to exhibit sensitivity to indigenous people in a trademark dispute involving the name "Redskins" for the Washington NFL football team. ${ }^{255}$ It concluded that the name brings disrepute to the native Americans based on an opinion poll, though the native Americans did not own a registered trademark. It is unclear whether the court was sensitive to the feelings of the Native Americans, or the rest of the United States in so deciding.

The judiciary seems to be in a constant dilemma between applying the statutory law or common law. This dilemma is between applying the right means or arriving at a logical, just decision. Unfortunately, statutory law is the right means but does not produce the right result. Common law and confidentiality theories provide the right result but it is not necessarily the right means.

\section{NATIONAL RESPONSES TO THE DEBATE ON TRADITIONAL KNOWLEDGE}

Most countries do not have adequate materials or mechanisms for protecting traditional knowledge. The value of the knowledge has prompted national efforts to legislate on traditional knowledge at different jurisdictions. The object of this part is to highlight the various methods used for such a protection to enable other countries to follow in these footsteps.

253. See id. at 1139.

254. See id.

255. See Harjo v. Pro Football, 50 U.S.P.Q. 2d 1705 (1999). 
This part discusses the attempts and the salient features of the legislative actions in the various jurisdictions.

\section{A. PHILIPPINES}

The Philippines was the first nation to legislate (Indigenous Peoples' Rights Act, 1997) to "protect and promote the rights of indigenous cultural committees/indigenous people.",56 The Act recognizes "community property" and advocates that the state shall set up necessary mechanisms to protect the culture and identity of the indigenous people. Section $2(\mathrm{~h})$ of the Act defines "indigenous people/ indigenous cultural communities," in very broad terms. ${ }^{258}$ Section 4 details that "Ancestral Lands/Domains" includes the land and the total environment - including spiritual and cultural bonds of the people with the land. ${ }^{259}$ The Act provides the indigenous people with the rights ${ }^{260}$ to (among other things) own, develop lands and natural resources, stay in the territories, resettle in case of displacement due to natural catastrophe, ancestral property,

256. This Act supplements the Philippines Constitutional mandates for the recognition and protection of the indigenous people. See The Indigenous Peoples' Rights Act of 1997 (visited Feb. 21, 2000) <http://www. ozamiz.com/earthcalls/ipra.html>.

257. See id. at $\$ 5$.

258. See Indigenous Peoples Rights Act, Ch. II, §2(h) (1997). Section 2(h) states:

Indigenous Cultural Communities/Indigenous Peoples refers to a group of people or homogenous societies identified by selfascription and ascription by other, who have continuously lived as organized community on communally bounded and defined territory, and who have, under claims of ownership since time immemorial, occupied, possessed customs, tradition and other distinctive cultural traits, or who have, through resistance to political, social and cultural inroads of colonization, nonindigenous religions and culture, became historically differentiated from the majority of Filipinos. ICCs/IPs shall likewise include peoples who are regarded as indigenous on account of their descent from the populations which inhabited the country, at the time of conquest or colonization, or at the time of inroads of non-indigenous religions and cultures, or the establishment of present state boundaries, who retain some or all of their own social, economic, cultural and political institutions, but who may have been displaced from their traditional domains or who may have resettled outside their ancestral domains.

Id.

259. See Ch. III, $\$ 4$.

260. See $\S \S 7-8$. 
and self government. ${ }^{261}$

\section{Intellectual Property Rights}

Section 32 establishes intellectual property rights on the indigenous people and communities. This section deems the existence of the right and reiterates that it cannot be taken away without: a) prior informed consent; or b) in violation of their laws, tradition and custom. ${ }^{262}$ However, "prior informed consent" has not been defined under the Act. Similarly, on a plain reading of section 32 , where there is no violation of their laws and customs, prior informed consent does not seem to be mandatory. ${ }^{263}$ The Act has created the National Commission on Indigenous People (NCIP). ${ }^{264}$ This is an independent agency under the Office of the President and is comprised of seven commissioners belonging to the indigenous communities in a particular area. ${ }^{265}$ The Act also sets out a minimum standard for qualification. ${ }^{266}$ The NCIP comprises offices for:

Ancestral Domain: identification, delineation and recognition of lands and domain;

Policy, planning and research: planning, more particularly 5 year plans;

Culture \& education: implementation of education, health, culture, related rights; and

Legal Affairs: resolves conflicts using Customary laws. ${ }^{267}$

The Act also provided for offices for Socio-Economic Services, Empowerment and Human Rights and Administration. ${ }^{268}$ This step by Philippines is significant, as it will be a forerunner to other countries that have been wanting to legislate on the subject.

\footnotetext{
261. See Indigenous Peoples Rights Act at Ch. III, §7.

262. See id. at Ch. VI, $\$ 32$.

263. See id.

264. See id. at Ch. VII, §38.

265. See Indigenous Peoples Rights Act at Ch. VII, $\$ 40$

266. See id. at Ch. VII, $\$ 41$. To qualify as a commissioner, the person must have worked for the indigenous communities for at least a minimum of ten years. At least two of the Commissioners must be members of the Philippines Bar, and each of them shall serve a term of three years and a maximum of six years. These appointments are made by the President from a list of people recommended by the Indigenous people themselves.
}

267. See id. at Ch. VII, $\$ 46$.

268. See id. 
B. INDIA

In India, where the awareness of intellectual property law is very low, the momentum towards protection of the indigenous properties increased after the texmati ${ }^{269}$ turmeric $^{270}$ and neem" disputes. The WTO and its "drug denying obligations" (high prices of drugs on account of product patent regime) served to increase this awareness.

As a consequence of this, in December 1998, the First Inter-Ministerial Committee on Protection of Rights of Holders of Indigenous Knowledge was convened. ${ }^{272}$ The discussions included protection of traditional knowledge and the possibility of introducing local self-government for administering the communities and their knowledge. The issue of identifying local communities was highlighted in this meeting. Many of the local communities have lost their traditional identity (over a period of time). The knowledge of this community has also become generic over a period of time. ${ }^{273}$ With this in mind, various bills, including the Protection of Plant Varieties and Farmers Rights Bill, 1999, ${ }^{274}$ and the Bio Diversity Bills of 1999

269. A hybrid variety of the native basmati rice which had a huge export potential. This was sought to be patented by Rice Tec which was objected to by India. There were three issues. First, there was an opposition to the patent application. Second, the name was deceptively similar to Basmathi, and the third issue was that the name Basmathi was a geographical indicator indicating rice grown in the India, Pakistan belt. However, India did not have a legislation to protect its geographical indicators and therefore lost the dispute (including the argument related to trademarks).

270. The application was filed by the University of Mississippi Medical Center to patent the wound healing property of turmeric in application No. 5401504. It was later challenged by the Council for Scientific Research in India. See also Posting of Jim Mcnulty, jim@niall7.demon.co.uk, to genetech@tribe.ping.de (Aug. 30, 1997) <http://www.gene.ch/genetech>.

271. The application for a patent was filed over an anti-fungal product by W. R. Grace, Inc. In June 1992, the USPTO granted patent No. 5,281,618 to W.R. Grace \& Co. for the same.

272. FiRst INTER Ministerial COMMITTEE ON PROTECTION OF RIGHTS OF HOLDERS OF INDIGENOUS KNOWLEDGE, MINISTRY OF EDUCATION (Sashtri Bhavan, New Delhi, December 1998) (on file with the author).

273. See supra note 125 . He also advocates that there is a need to find out democratic institutional arrangements (e.g. trusts, collectives, and cooperatives) with the involvement of the representatives of all the traditional users or develop such institutions at various levels to solve possible conflicts that may arise regarding the management and use of traditional knowledge of the various communities. See id.

274. Protection of Plant Varieties and Farmers Bill, 1999, Compendium of New IP Legislations, 2000, Vidhi Publications, New Delhi, 2000. 
were drafted. ${ }^{275}$

The Protection of Plant Varieties and Farmers Rights Bill, 1999, was drafted to protect the plant breeders and farmers, to encourage the development of new varieties of plants, and to attempt to conform with Article 27(b)(3) of TRIPS. Notably, the definition of plant excludes micro-organisms. ${ }^{276}$ Section 3 provides for the establishment of an authority to protect the rights of the breeders and the farmers, promote new plant varieties, maintain a system of registration of new plant varieties, $^{277}$ and catalog and maintain registration of the varieties, and collect statistics. ${ }^{278}$

The other important legislation, The Bio Diversity Bill, $1999,^{279}$ includes within the fold of biological diversity: living creatures from all sources; diversity within species, between species and of ecosystems; but, excludes human genetic material. ${ }^{280}$ It establishes national, state Biological Diversity Authority, the Biodiversity Management Committees in local bodies, and a National Benefit Fund to deposit money collected from benefit sharing. ${ }^{281}$ Section 11 prohibits the taking away of the biological resources by any person without the prior

275. There have been six such drafts. See A BRIEF OUTLINE of THE BIOLOGICAL DIVERSITY ACT, 1998; MINISTRY OF ENVIRONMENT AND FORESTS, BIO DIVERSITY (RIGHTS AND PROTECTION) BILL, 1998; Draft of the Research Foundation, Lawyers Collective, 1998; REPORT OF THE EXPERT COMMITTEE ON BIOLOGICAL DIVERSITY CONSTITUTED BY THE MINISTRY OF ENVIRONMENT AND FORESTS UNDER THE CHAIRMANSHIP OF DR. M. S. SWAMINATHAN (the Report proposed an outline of the Biological Diversity Act, 1998); DRAFT OUTLINE OF The NATIONAL Bio Diversity Legislation, Proposed by the TWN network, Dr. Vandana Shiva, Published by the Research Foundation for Science, Technology and Ecology, New Delhi (copy on file with the author); and THE REVISED PROPOSAL FOR THE NATIONAL BIOLOGICAL DIVERSITY ACT, 1999, MINISTRY OF ENVIRONMENT AND FOREST, NEW DELHI (copy on file with the author).

276. Section 2 of The Protection of Plant Varieties and Farmers Rights Bill, 1999, defines plant as "cultivated plants or anything that belonged to the plant kingdom and specifically excludes the micro-organisms."

277. This provides for collective rights through the terms and conditions that are built in it. This along with the provision that secures the traditional rights of framers are considered to demarcate itself from the Union for Protection of Plant Varieties.

278. See id. at $\$ 8$.

279. There have been nearly six versions of the Bill so far, each draft was attempted to be conformity with the Convention on Biological Diversity. This note considers the proposed legislation by the Ministry of Environment and Forests. See supra note 213 for the various versions of the proposal.

280. See BIO DIVERsiTy BILL $§ 2,1999$, GovernMENT OF INDIA, MiNISTRY OF ENVIRONMENT.

281. See id. 
informed consent from the National Authority. Applications for consent are made to the National Authority which will decide on the amount of royalties payable. Contravention of these provisions can result in a fine of up to one lakh rupees and a minimum of five years imprisonment. ${ }^{282}$

The Bill, however, does not empower the local bodies with any participation to decide whether or not a requested resource can be shared and the amount of royalty. This is significant because, more often than not, the members of the local bodies are more likely to have first hand knowledge of the local biodiversity and its use. The head office, located in Delhi, is completely removed from the respective locality where the resource is available. Therefore urban authorities working several hundred miles away in a country the size of India will have difficulty in accessing, or even knowing the importance of, the resource. The various Bills and Amendments were a long overdue step for India. This is also a show of increased awareness for intellectual property regimes, not only for the protection of biodiversity and traditional knowledge, but also of industrial properties.

\section{THAILAND}

Thailand introduced legislation to protect the knowledge of the traditional healers and medicinal resources from private appropriation by pharmaceutical companies. ${ }^{283}$ Multinational corporations influence farming in Thailand on account of pesticides and insecticides. They succeeded in getting two Bills passed. One was passed by the Ministry of Agriculture and Cooperatives, and the Ministry of Commerce passed the other. The object of both the bills was for protecting exclusive rights of new plant varieties. These include Thai export crops such as rice, maize, orchids, rubber, and wheat. ${ }^{284}$ The farmers' lobby opposed both the Bills, as there was no provision for benefit sharing. The lobby was particular about provisions relating to farmers' privilege, farmers' rights, and protection of traditional

282. Id

283. When the drafting of the Bill was yet to be completed the U.S. Embassy suggested that it was violative of TRIPS and will block medical research resulting in a protest from the nongovernmental organizations

284. Chakravarthi Ragavan, U.S. Tries to Block Thai Moves on Traditional

Knowledge, Third World Network, (visited Feb. 21, 2000) <http://www.twnside.org.sg/title/thi-cn.htm>. 
plant varieties to be included. ${ }^{285}$ This is a reflection of the awareness of their rights by farmers which was not prevalent until recently. ${ }^{286}$ As a response, the Government appointed a Committee for drafting the Plant Variety Protection Bill. ${ }^{287}$ This Committee, which includes farmers, combined the two bills into one single Bill. This new Bill follows the sui generis option of Article 27.3(b) of TRIPS, thereby allowing for the possibility of including farmers' privilege. ${ }^{288}$

\section{AFRICA}

In February of 2000, a proposal to incorporate African traditional medicine into the National Policy Plan for Africa was accepted. ${ }^{289}$ The recommendations stressed the importance of strengthening the quality of rural health care by exploring, encouraging, and improving the use of traditional plant-based medicines, on which a large proportion of the African population still depends for effective, low-cost health care. The recommendations were made on African traditional medicine argued that indigenous traditional medicines provide low-cost remedies for rural health care. It was recommended that even the developed nations should explore, and encourage the rational use of low- tech traditional medicine. It also urged the governmental and nongovernmental organizations to create

285. Compeerapap Jaroen, The Thai Debate on Biotechnology and Regulations, 32 BIO TECHNOLOGY AND DEVELOPMENT MONITOR 13 (Sept. 1997).

286. See 4-PATENTS: Developing Countries Preparing Non-UPOV "sui generis" Plant Variety Protection Schemes, Biological Russian Roulette (visited Feb. 21, 2000) <http://www.gene.ch/genet/Aug.htm>. This article states that Thailand's draft Plant variety Protection Bill distances itself from UPOV in the following manner:

1. Define classes of plant varieties with rights and responsibilities attached to each domestic, new, general domestic and wild plant varieties.

2. Trans genic varieties are subject to special biosafety reviews.

3. Duration of protection is 12,17 or 27 years depending on the type of plant.

4. Exhaustion of the plant breeder's right in terms of farmers' cultivation practices is more ample (farmers get broad rights to use protected material).

5. Creates a plant variety protection fund aimed at supporting research and development of plant varieties.

6. It requires profit-sharing agreements in the case of general domestic and wild plant varieties, the revenue from which shall accrue to the Fund.

287. See id.

288. See id.

289. It was accepted at the National Summit on Africa that was held in Washington, D.C. 
and support education and use of traditional medicines. The plan also suggested that US should encourage and support research and development to modernize techniques for producing safe, stable, and natural health care products. ${ }^{290}$ These were incorporated into the fiscal policy plan.

Interestingly, Benin and Rwanda are the only countries in the world whose copyright laws explicitly embrace "scientific and technological" folklore in their definitions. The National Folklore Board of Trustees of Ghana explicitly includes "traditional technology" and "traditional medicine" as forming part of the nation's culture. ${ }^{292}$ The various initiatives by individual countries will possibly pave a way for the evolution of a system for this area of law. Most of these countries lack a good patent regime, or any other intellectual property regime.

\section{CONCLUSION}

Today, the indigenous people are in the crossroads between intellectual property and a sui generis regime. A backward look at the time chart gives the impression that the naivete of the people vis-à-vis their rights coupled with the willingness to share knowledge resulted in exploitation leading to depletion, dilution, erosion and misuse of the knowledge. ${ }^{293}$ Third parties gained undue benefits. The disparity in wealth between the knowledge holders and those benefited, highlighted the need to prevent the misuse and vest rights. The indigenous societies seemed to have looked upon WIPO, the U.N. and other world bodies for support. However, there has been an undue delay in providing an effective regime. Moreover, the efforts taken by these bodies in the form of Conventions and Declarations were

290. The final policy plan was presented at the National Summit to Gene B. Sperling, Assistant to the President for Economic Policy to be presented to the Congress. See id.

291. See Evelyn Leigh, McCaleb's Traditional Medicine Agenda Added to National Plan of Action for Africa, Herb Research Foundation (visited Feb. 21, 2000) <http://www.herbs.org/current/tradafrica.html>.

292. Witoon Lianchamyoom \& Renée Vellvé, Sign Posts to Sui generis Rights-The International Context of the Sui Generis Rights Debate by GRAIN, International Seminar on Sui generis Rights (visited Feb. 21, 2000) $<$ http://www.grain.org/publications/sighposts.htm>.

293. See Cathryn A Berryman, Towards More Universal Protection of Intangible Cultural Property, 1 J. INTEL. PROP. LAW 293 (1994) (highlighting the importance of protection and the danger of destruction and points out that the people and their cultures are victims of integrity violations and suffer mutilations, destruction and distortion). 
unclear and not uniform. Important concepts such as "community rights" and "common goals in Conventions" were not researched. Conventions like the Berne, important in the intellectual property regime, did not recognize indigenous property rights. The reality that after over a decade of research, not a single acceptable model or framework has emerged resulted in an acute sense of unfair treatment especially against the backdrop of the TRIPS deadlines.

The indigenous people interpreted this delay as lack of interest and clarity. They perceive that such contradictions would have been taken seriously was this regarding the prevailing intellectual property rights. It is impossible to conceive a situation where the Berne Convention gives a right which TRIPS restrains. There are several such instances of contradictions between Conventions and Declarations in the case of traditional knowledge. This reduced confidence resulted in the indigenous people renouncing the western-originating system completely. Such a renunciation is reflected in the Bellagio and later, in the Suva Declarations. That they are open to working with the prevailing mechanisms is the good news as seen from the COICA statement. ${ }^{294}$ The movement from complete dependency to total renunciation of the intellectual property regime is a warning that it may not be too long before these people lose all faith and hope in the system. It may lead to the creation of a parallel system stunting research and development in some areas. Importantly, the coveted theme of the WTO, "uniformity at any cost," will be in short supply. That such a parallel system, if it emerges, may not be within the crushing powers of the WTO is also something that can cause concern to the nations, as trade sanctions will have little effect on these people. On the other hand, it may take a long time before these protests strengthen to become a force to be reckoned with.

Unfortunately, the courts are the only forum that could have possibly shown some sensitivity and tried to strike a balance between the systems. However, even the Australian courts, which deal with a good number of cases involving the indigenous people, seem to be far less sensitive. There seems to be trend towards favoring the application of the prevailing

294. It is a reality that the support of the world bodies is essential for even establishing and recognizing these rights internationally. Hence the COICA statement declared that the indigenous people are open to the prevailing system so long as it is not disadvantageous to them. 
intellectual property system. This becomes absurd in the context of the indigenous people. It is similar to applying common law blindly for disputes in a private international law disputes involving members from civil jurisdiction. Applying a law and a legal system that is alien to parties whose rights the law seeks to protect does not fall within the basic structure of the legal system. The Morning Star Case discussed above is a classic example of the courts' insensitivity toward community rights. It is impossible for a reader not to think that perhaps the problems arising from withdrawing already circulated Reserve Bank currencies was the reason for the Court's refusal to look at the obvious and stick to its application of the prevailing system.

Australia is no lone ranger. The USPTO is not far behind in vesting patent rights to individuals for property in public domain elsewhere. ${ }^{295}$ It is difficult to digest that the powerful WTO and WIPO have not yet seriously considered taking a stand and implementing the same. Looked at from this angle, it is no wonder that the indigenous people who were initially more confident of solutions through the western bodies have started renouncing the same. The courts and intellectual property experts have criticized that the indigenous people should ensure there is a codified law before seeking recognition. In countries like America and Australia this may be something that can be achieved where the lawmaker and the indigenous people can coordinate codification. However, there are also places in remote corners of India, the Amazon, and various African countries, where the holders of this knowledge who do not operate by codified laws. They will also not be able to appreciate the nuances. Expecting them to codify is, to say the least, a joke. Our recognition of the British Constitution proves that codification is not essential for recognition - or is it only for the blue-blooded? 